DOI 10.4467/2543733XSSB.16.011.6253

MIRELLA KORZENIEWSKA-WISZNIEWSKA

Uniwersytet Jagielloński

\title{
POLITYKA ETNICZNA REPUBLIKI SERBII WOBEC WYBRANYCH MNIEJSZOŚCI PO 2009 ROKU
}

Słowa kluczowe: polityka etniczna Serbii, mniejszości w Serbii, Boszniacy w Sandżaku, Sandżak, mniejszość albańska, Preszewo, Bujanovac, Medveđa, Wojwodina, mniejszości w Wojwodinie ${ }^{1}$

\section{Pojęcie polityki etnicznej - zamiast wstępu}

Pojęcie polityki etnicznej, znajdujące zastosowanie w interdyscyplinarnych badaniach z zakresu socjologii, antropologii, etnografii czy politologii, trudne jest do ujęcia w jednej definicji ze względu na tę wielopłaszczyznowość lub wieloaspektowość badań w odniesieniu do konkretnego przykładu. Henryk Chałupczak wskazuje na fakt, że z punktu widzenia paradygmatu badań politologicznych pojęcie polityki etnicznej (funkcjonujące zamiennie jako: polityka mniejszościowa, etnopolityka czy polityka narodowościowa lub też polityka wobec mniejszości narodowych i etnicznych) najwłaściwiej może być interpretowane dosłownie jako polityka wobec mniejszości narodowych i etnicznych. Taka definicja nie daje jednak wyobrażenia o różnorodności relacji etnicznych, z którymi można się spotkać w obrębie badań nad mniejszościami narodowymi lub etnicznymi², stanowiącymi

${ }^{1} \mathrm{~W}$ tekście stosowane są istniejące spolszczone nazwy regionów i miejscowości w Republice Serbii. Część jednak nie posiada polskich zapisów, stąd ich pisownia pozostała oryginalna. Z kolei w mapach zamieszczonych poniżej została zachowana oryginalna pisownia celem ujednolicenia obrazu.

${ }^{2}$ W różnych dziedzinach nauki, zajmujących się badaniem różnorodnych płaszczyzn życia mniejszości narodowych oraz etnicznych w ostatnich latach, pojawiła się tendencja do używania określenia grupa etniczna w odniesieniu do wszystkich społeczności mniejszościowych, nawet tych różniących się na danym obszarze statusem prawnym (czyli zarówno wobec narodów konstytucyjnych/tytularnych, w odniesieniu do ich pochodzenia, jak i mniejszości). W artykule autorka będzie posługiwać się pojęciem mniejszości zgodnie z nomenklaturą ustawodawstwa serbskiego, które stosuje określenie mniejszości narodowe w odniesieniu do wszystkich przedstawicieli ludności nieserbskiej na obszarze Republiki Serbii, zob. art. 14 i 76 Konstytucji Serbii z 2006 r. i art. 2 Ustawy o ochronie praw i wolności mniejszości narodowych, Устав Републике Србије. 2006, http://www.parlament.gov.rs/upload/documents/Ustav_Srbije_pdf.pdf, Zakon o zaštiti prava i sloboda nacionalnih manjina, (,,Sl. List SRJ”, br. 11/2002, „Sl. List SCG”, br. 1/2003 - Ustavna povelja I “Sl. Glasnik RS”, br. 72/2009 - dr. zakon I 97/2013 - odluka US, http://www.paragraf.rs/propisi/zakon_o_zastiti_prava_i_sloboda_nacionalnih_manjina. html (dostęp 11. 04. 2016 r.). 
nieodłączne komponenty tej definicji, co dobrze prezentują badacze, zwłaszcza z obszaru Europy Wschodniej, wskazani przez Henryka Chałupczaka ${ }^{3}$.

Z kolei Radosław Zenderowski przytacza dwa paradygmaty myślenia o polityce etnicznej, które pozostają w opozycji. Pierwszy z nich przedstawia politykę etniczną jako konflikt etniczny związany z napięciami wokół redystrybucji ograniczonych zasobów materialnych i niematerialnych między poszczególne grupy etniczne (który może zostać ujęty również jako Hobbesowski paradygmat walki wszystkich ze wszystkimi o ograniczone zasoby). Drugi paradygmat ujmuje politykę etniczną jako współpracę międzyetniczną, której celem jest wzajemne uzgadnianie interesów poszczególnych grup etnicznych lub narodowych $i$ dażenie do zachowania pokojowych stosunków między tymi grupami w ramach jednego państwa (Kantowski paradygmat racjonalnej wspótpracy na bazie przekonania, że stosunki społeczne nie sa gra o sumie zero $i$ że konflikt generuje straty po obydwu stronach, podczas gdy kooperacja zwiększa zyski wszystkich uczestników), przy czym polityka etniczna jest najczęściej przedstawiana właśnie jako pierwszy paradygmat, który wskazuje na pewne postawy w relacjach etnicznych, takie jak:

a. Zachowanie lub umocnienie uprzywilejowanej pozycji narodu tytularnego kosztem innych grup etnicznych i narodów;

b. Postępująca, planowa i zorganizowana marginalizacja społeczna, kulturowa, polityczna i ekonomiczna grup mniejszościowych lub świadome ignorowanie potrzeb i interesów mniejszości;

c. Ewentualna eliminacja mniejszości (...) poprzez asymilację, wysiedlenia, wypędzenia, a nawet zorganizowane ludobójstwo ${ }^{4}$.

W poniższym tekście zostanie dokonana analiza serbskiej polityki etnicznej, rozumianej jako całościowy charakter działalności państwa w odniesieniu do wybranych grup mniejszościowych (relacje etniczne w wymiarze wertykalnym), jak i faktycznego położenia tychże mniejszości oraz relacji w ich obrębie (relacje w wymiarze horyzontalnym). Ze względu na ograniczoną objętość artykułu, analizie komparatywnej poddane zostaną trzy obszary, charakterystyczne dla ujęcia polityki etnicznej Republiki Serbii: Wojwodina, Sandżak oraz położone na południu Serbii trzy gminy, zamieszkałe przez mniejszość albańską: Preszewo, Bujanovac i Medveđa ${ }^{5}$ Cezura czasowa opiera się na dacie uchwalenia ostatniej Ustawy o ochronie praw $i$ wolności mniejszości narodowych $w$ Republice Serbii, co z uwzględnieniem wcześniejszych regulacji w tym zakresie daje obecnie pełną listę aktów prawnych jako jednego z zasadniczych komponentów polityki etnicznej państwa.

${ }^{3}$ H. Chału p c z a k, Paradygmat badawczy polityki etnicznej jako polityki publicznej państwa, [w:] Polska i Europa wobec wyzwań współczesnego świata. Mniejszości narodowe i etniczne w Polsce i Europie. Aspekty polityczne i społeczne, red. A. Sakson, Wyd. Adam Marszałek, Toruń 2013, s. 11-28.

${ }^{4}$ R. Zen d e row s ki, Polityka etniczna - próba (re)konceptualizacji, [w:] Polityka etniczna. Teorie, koncepcje, wyzwania, red. H. Chałupczak, R. Zenderowski, E. Pogorzała, T. Browarek, Wydawnictwo UMCS, Lublin 2015, s. 32.

${ }^{5}$ Gminy te sąsiadują z Kosowem zamieszkałym również przez Albańczyków. Brak uregulowanego statusu obszaru kosowskiego oraz trudne relacje na linii Belgrad i Prisztina, po wojnie w 1998-1999 r., oddziałują w bezpośredni sposób na sytuację w Dolinie Preszewa i w pozostałych miejscowościach. 


\section{Regulacje prawne dotyczące mniejszości narodowych i etnicznych w Republice Serbii}

Według spisu narodowego z 2002 r., na który powołują się władze Republiki Serbii, grupy etniczne (zarówno mniejszości narodowe, jak i etniczne) stanowiły 17,14\% ogółu ludności. Mniejszości żyją w stosunkowo homogenicznych skupiskach, przy czym ich większość zamieszkuje Autonomiczną Prowincję Wojwodiny (APW), na obszarze której stanowią 34, 95\% (710 185) ludności, zaś w Serbii Centralnej 10, 52\% (574 978). Wyjątek stanowią Romowie zamieszkujący całe terytorium państwa ${ }^{6}$.

Tworzenie aktów prawa regulujących charakter umiejscowienia grup etnicznych w przestrzeni społecznej danego państwa jest jednym z narzędzi polityki etnicznej prowadzonej przez państwo. W przypadku Republiki Serbii politykę wobec mniejszości po rozpadzie Socjalistycznej Federacyjnej Republiki Jugosławii zaczęto regulować jeszcze w latach 90. XX w., wprowadzając w przepisach prawnych akty, które stwarzały pozory spełniania standardów europejskich. Przepisy te były jednak martwą literą, której realizacja nie była możliwa ze względu na brak woli władz państwowych oraz niemożność egzekwowania swych praw przez same mniejszości, ze względu na dysfunkcyjność systemu politycznego o niedemokratycznym charakterze. W okresie transformacji politycznej i gospodarczej, który w Serbii rozpoczął się po roku 2000, sięgano w niektórych rozwiązaniach (w tym mniejszościowych) do tradycji zachodnioeuropejskich, nawiązując do dokumentów międzynarodowych, na podstawie których uchwalano wewnątrzpaństwowe akty prawne, mające celować w standardy Unii Europejskiej. Były to m.in.: Akt Końcowy KBWE, dokumenty Rady Europy i Komisji Europejskiej, Ramowa Konwencja o Ochronie Praw Mniejszości, Europejska Karta o Językach Regionalnych i Mniejszościowych, zaś aktów wewnątrzkrajowych, regulujących kwestie mniejszościowe, możemy znaleźć ponad dwadzieścia, spośród których dla charakterystyki polityki etnicznej trzeba wymienić: Konstytucję Republiki Serbii z 2006 r., Ustawę o ochronie praw i wolności mniejszości narodowych z 2002 r. (nowelizowana ostatni raz w 2009 r., a opatrzona komentarzem Trybunału Konstytucyjnego w 2013 r.), Ustawę o urzędowych językach i piśmie, Ustawę o podstawach systemu ksztatcenia $i$ wychowania z $2004 \mathrm{r}$. (nowelizowaną ostatni raz w 2010 r.), Ustawę o samorzadzie lokalnym (z lat 2007-2014). Należy jeszcze nadmienić, że dodatkowe regulacje związane z położeniem mniej-

${ }^{6}$ Liczba Romów wg spisu z 2011 r. wynosi 140 604, jednak według oficjalnych szacunków wynosi 450 tys. Należy nadmienić, że w spisie powszechnym z 2002 r. jako Serbia Centralna przedstawiany jest cały obszar poza AP Wojwodiną. Ten podział nie występuje już w spisie z 2011 r., Коначни резултати пописа 2002. Становништво према националној или етничкој припадности и према полу и старости у Републици Србији, по општинама, Саопштење број 295 • год. LII, 24.12.2002, Република Србија. Републички завод за статистику, http://www.mtt.org.rs/Srbijapopis2002.pdf, s. 2, Попис становништва, домћинства и станова 2011. у Републици Србији. Наионална припадност. Подаци по општинама и градовима, Република Србија, Републички завод за статистику, http://pod2.stat.gov.rs/ObjavljenePublikacije/Popis2011/ Nacionalna\%20pripadnost-Ethnicity.pdf, s. 14, N. Gojković, Sistem zaštite manjina u Republici Srbiji, http:// www.kas.de/upload/auslandshomepages/serbien/Gojkovic_pred.pdf, s. 4 i 5, Potpisani ugovori za samozapošljavanje Roma u Vojvodini Vlade Autonomne Pokrajine Vojvodine, 29. 12. 2011, http://www.vojvodina.gov.rs/ index.php?option $=$ com_content\&task $=$ view\&id=6270\&Itemid=2, Uručeno 260 ugovora za samozapošljavanje, RTV 13.07. 2011, http://www.rtv. rs/sr_lat/vojvodina/uruceno-260-ugovora-za-samozaposljavanje_263463. html (dostęp 4. 04. 2016 r.). 
szości zostały zawarte w ramach umów bilateralnych z Chorwacją, Macedonią, Węgrami oraz Rumunią?

Serbskie normy prawne, zgodnie $\mathrm{z}$ wymogami unijnymi ${ }^{8}$, zapewniają mniejszościom pełną ochronę, począwszy od ustawy zasadniczej z 2006 r., gdzie w art. 14 znajdziemy gwarancję pełnego równouprawnienia i poszanowania tożsamości etnicznej, co chronione jest prawami kolektywnymi (z zakresu kultury, kształcenia, informacji i stosowania języka w zakresie urzędowym w mowie i piśmie) oraz indywidualnymi (art. 75 i 76). Istnieje jednak pewien przepis - zdaniem autorki - dość kontrowersyjny, zgodnie z którym jako dyskryminacji nie postrzega się osobnych przepisów i środków doraźnych (tymczasowych), które Republika Serbii może wprowadzić w życiu ekonomicznym, socjalnym, kulturalnym i politycznym, w celu osiagnięcia pelnej równoprawności między przedstawicielami mniejszości narodowych i obywatelami, którzy przynależa do większości, jeśli sa skierowane na zniesienie istniejacych niekorzystnych warunków życia ${ }^{9}$. Ustawa zasadnicza zapewnia również przedstawicielom mniejszości równouprawnienie w zatrudnieniu w sektorze państwowym i w piastowaniu funkcji publicznych. Co więcej, przy zatrudnianiu w organach państwowych, urzędach, organach $w$ prowincji autonomicznej i jednostkach samorzadowych prowadzi się metodę zatrudniania wedtug klucza narodowościowego, odpowiadajacego reprezentacji mniejszości narodowych ${ }^{10}$ (art. 77). Przepisy zabraniają przymusowej asymilacji, gwarantując prawo do wyrażania, ochrony i rozwijania swojej odrębności etnicznej, kulturowej i religijnej. Przedstawiciele mniejszości narodowych mogą także używać swoich symboli w miejscach publicznych, jak i swojego języka w formie mówionej i pisanej. Jeśli mniejszość stanowi liczniejszą populację, wówczas w urzędach, organizacjach i innych jednostkach samorządowych możliwe jest prowadzenie postępowania w różnych kwestiach w swoim języku. Takie samo rozwiązanie zapewnione zostało w systemie szkolnictwa i instytucjach, przy korzystaniu ze swojego imienia i nazwiska, w nazewnictwie ulic, miast i wsi ${ }^{11}$. Konstytucja Serbii gwarantuje również przedstawicielom mniejszości zakładanie stowarzyszeń o charakterze oświatowym i kulturalnym, które są dobrowolnie finansowane. Maja również prawo do utrzymywania więzi $i$ wspótpracy z rodakami spoza terytorium Republiki Serbii ${ }^{12}$.

Z Konstytucją koresponduje Ustawa o ochronie praw i wolności mniejszości z 2009 r. (jest to ostatnia nowelizacja ustawy z 2002 r.), która przede wszystkim definiuje mniejszość narodową jako grupę obywateli, nazywająca się lub określająca jako naród, wspólnota narodowa i etniczna, grupa narodowa i etniczna, narodowość oraz jednostka o innym pochodzeniu etnicznym, która jest grupa obywateli powiązana dlugotrwała więzia z terytorium Zwiazkowej Republiki Jugosławii i posiada charakterystyczne cechy, jak odrębny język, kulturę, przynależność narodowa lub etniczna, pochodzenie lub wyznanie, czym

${ }^{7}$ Zob. więcej na ten temat Заштитик грађана. Омбудсман. Права мањина, http://www.pravamanjina. rs/ (dostęp 11. 04. 2016 r.).

${ }^{8}$ Serbia miała otrzymać status kandydata do Unii Europejskiej w drugiej połowie 2011 r., podczas polskiej prezydencji. W grudniu tego roku stwierdzono, że UE wstrzymuje się z przyznaniem tego statusu, zaś jedną z głównych przyczyn była kwestia mniejszościowa, co do której wątpliwości zgłosiła Rumunia.

9 Устав ...

${ }^{10}$ Ibidem.

${ }^{11}$ Ibidem.

12 Ibidem. 
odróżnia się od większości mieszkańców, i której członkowie zabiegaja o utrzymanie swojej wspólnotowej tożsamości, uwzględniając kulturę, tradycję, język i religię ${ }^{13}$. Spośród 169 gmin w Republice Serbii 68 jest wieloetnicznych. Zgodnie z Ustawa o samorzadzie lokalnym z 2002 r. (znowelizowaną w 2006 r.) jest nią taka gmina, której przynajmniej $5 \%$ mieszkańców stanowią przedstawiciele jednej grupy mniejszościowej lub minimum $10 \%$ stanowią przedstawiciele większej liczby mniejszości ${ }^{14}$.

Z perspektywy polityki etnicznej na szczególną uwagę zasługują przepisy regulujące kwestie posługiwania się językiem, tworzenia organów reprezentacyjnych przedstawicieli mniejszości oraz możliwość posługiwania się symbolami narodowymi.

Według przepisów o stosowaniu języka urzędowego w jednostkach samorządu lokalnego, język może być stosowany tam, gdzie przedstawiciele danej mniejszości stanowią powyżej $15 \%$ obywateli (co wymienione jest również w art. 11 Ustawy o ochronie praw $i$ wolności mniejszości narodowych). Jeśli chodzi o interesujących nas w tym tekście przedstawicieli mniejszości albańskiej i boszniackiej, to albański jest językiem służbowym w Preszewie, Bujanovcu i Medveđi, zaś język bośniacki w gminach sandżackich, w których Boszniacy stanową większość: Sjenica, Tutin i Novi Pazar. W Wojwodinie stosowanych jest aż sześć języków służbowych i oprócz serbskiego są to: węgierski, słowacki, chorwacki, rumuński i rusiński (w miejscowości Bela Crkva dopuszczane jest stosowanie języka czeskiego). Warto nadmienić, że w centralnej Serbii występują cztery języki służbowe: serbski, bośniacki, albański i bułgarski w południowo-wschodniej części, przy granicy z Bułgarią ${ }^{15}$.

Kwestia nauczania w językach mniejszości jest regulowana szczegółowo przez Ustawę o podstawach systemu ksztatcenia i wychowania z $2004 \mathrm{r}$. oraz Ustawę o samorzqdzie lokalnym. Według ich brzmienia możliwe jest kształcenie przedstawicieli mniejszości w swoim języku, pod warunkiem że będzie co najmniej 15 uczniów. Istnieje również możliwość dwujęzycznego kształcenia oraz nauki w języku mniejszości z elementami kultury na temat danej mniejszości. Należy jednak podkreślić, że nauka języka serbskiego jest obowiązkowa ${ }^{16}$.

Organem reprezentującym mniejszości na poziomie centralnym jest Rada ds. mniejszości narodowych (Savet za nacjonalne manjine Zaštitnika građana), podlegająca ombudsmanowi Serbii. Na poziomie lokalnym mniejszości tworzą związki narodowe (obecnie w serbskim państwowym rejestrze związków narodowych figuruje 21 związków mniejszościowy $\mathrm{ch}^{17}$ ), których reprezentanci wchodzą w skład instytucji centralnej; wybory do związków narodowych odbywają się co cztery lata, a ich działalność i zakres kompetencji reguluje Ustawa o zwiazkach narodowych mniejszości narodowych z 2014 r. ${ }^{18}$

${ }^{13}$ Zakon o zaštiti prava...

${ }^{14}$ Zakon o lokalnoj samoupravi, ,Sl. glasnik RS", br. 129/2007 i 83/2014 - dr. zakon", http://www.paragraf.rs/propisi_download/zakon_o_lokalnoj_samoupravi.pdf (dostęp 10.04. 2016 r.).

${ }_{15}$ Zakon o zaštiti prava..., Статут Аутономне Покрајине Војводине, 2014, http://www.skupstinavojvodine.gov.rs/fajlovi/file/Statut/Statut\%20AP\%20Vojvodine.pdf (dostęp 12. 04. 2016 r.), N. Gojković, op. cit., http://www.kas.de/upload/auslandshomepages/serbien/Gojkovic_pred.pdf, s. 2, dostęp 11. 04. $2016 \mathrm{r}$.

${ }^{16}$ Jeśli liczba 15 uczniów nie została osiągnięta, to minister oświaty może wydać specjalną zgodę na prowadzenie zajęć dla mniejszej grupy, N. Gojk ović, op. cit., s. 9.

17 Заштитик грађана...

${ }_{18}$ Savet za nacjonalne manjine Zaštitnika građana, Заштитик грађана. Омбудсман. Права мањина, http://www.pravamanjina.rs/index.php/sr_YU/component/content/article/334, Zakon o nacionalnim savetima 
Kontrowersyjne są regulacje dotyczące posługiwania się symbolami i znakami narodowymi, ponieważ w tej kwestii przepisy konstytucji - zdaniem mniejszości - pozostają w sprzeczności z ustawami. Jak wspomniano powyżej, Konstytucja w art. 79 potwierdza prawo do posługiwania się swoimi symbolami w miejscach publicznych, jednak Ustawa o ochronie praw $i$ wolności mniejszości narodowych $\mathrm{w}$ art. 16 zastrzega, że symbole i znaki, do których wyboru i stosowania mniejszość ma prawo, nie mogą być identyczne ze znakami i symbolami innych państw, co w praktyce nie pozwala np. Albańczykom na wywieszanie flag Albanii, czy Boszniakom flag Bośni i Hercegowiny. Wyjątkiem są święta państwowe tych krajów (oraz oczywiście pozostałych, których mniejszości zamieszkują Serbię), odnotowane w oficjalnym kalendarzu państwowym, kiedy eksponowanie symboli narodowych tychże państw jest dozwolone. I o ile zakaz wystawiania flagi narodowej przez mniejszość może zasługiwać na krytykę, o tyle dosłowne brzmienie przepisów nie jest z sobą sprzeczne, bo Konstytucja nie uściśla, o jakie symbole chodzi, pisząc o swoich symbolach, które posiada mniejszość, co z kolei precyzuje Ustawa, mówiąc, że są to ustalone i przyjęte przez daną mniejszość symbole, inne niż państwowe danego narodu ${ }^{19}$.

\section{Etnopolityka na wybranych obszarach Republiki Serbii}

W polityce etnicznej Republiki Serbii najbardziej istotna i zbliżona do rzeczywistego obrazu tej polityki jest płaszczyzna regionalna, a w jej ramach stan relacji na linii pań-

nacionalnih manjina, ,Sl. glasnik RS br. 72/09 , 20/14 - US, 55/14”, http://www.mduls.gov.rs/doc/dokumenta/ nac-manjine/zakon\%20o\%20nacionalnim\%20savetima\%20nacionalnih\%20manjina.pdf, Izbori 2014. Za nacjonalne savete nacionalnih manjina, Minority news, http://izbori.minoritynews.rs/nacionalni-savet-albanske-nacionalne-manjine (dostęp 11. 04. 2016 r.).

19 Sytuacja ta wzbudza największy sprzeciw wśród społeczności albańskiej z południa Serbii. Warto dodać, że w zakresie kompetencji jednostek samorządowych jest: tworzenie organizacji i instytucji o charakterze publicznym; umożliwienie funkcjonowania zgodnie z prawem społeczności lokalnych i inicjatyw obywatelskich; współpraca z zagranicznymi jednostkami tego samego szczebla pod warunkiem, że ta działalność będzie zgodna z polityką zagraniczną Republiki Serbii; tworzenie planów rozwojowych i urbanistycznych; przyjmowanie i zamykanie budżetu; zatwierdzanie źródeł przychodu gminy, wysokości podatków oraz innych opłat; zarządzanie gospodarką komunalną, transportem, utrzymanie czystości gminy, konserwacja i remont budynków, dróg i miejsc publicznych, oświetlenie gminy; eksmisja lokatorów nielegalnie zajmujących pomieszczenia i budynki publiczne; zarządzanie gruntami o charakterze budowlanym; dbanie o ochronę środowiska; zarządzanie rezerwami surowcowymi we współpracy z odpowiednim ministerstwem; organizacja odpowiednich instytucji w zakresie szkolnictwa podstawowego, kultury, opieki zdrowotnej, sportu, turystyki, ochrony socjalnej i usług społecznych; działań zmierzających do ochrony dziedzictwa kulturowego gminy oraz wsparcie dla działalności kulturalnej; organizacja zabezpieczenia w zakresie podstawowym przed klęskami żywiołowymi; ochrona użytków rolnych; zarządzanie gospodarką wodną; zarządzanie majątkiem gminy; organizacja różnych form solidarności i samopomocy wobec osób znajdujących się w trudnym położeniu w porównaniu z resztą społeczności; wsparcie rozwoju spółdzielni; organizacja pomocy prawnej dla obywateli; działania w zakresie ochrony i realizacji praw indywidualnych i zbiorowych mniejszości narodowych i grup etnicznych; decydowanie o stosowaniu języka służbowego mniejszości zamieszkującej daną gminę; zapewnienie informacji o zakresie lokalnym w języku serbskim oraz językach mniejszości, stosowanych urzędowo w gminie, postawienie stacji telewizyjnych i radiowych celem zapewnienia odbioru programów w językach mniejszości oraz raportowanie stosowania języków w przypadku, gdy nie są one ustanowione w danej gminie jako urzędowe, Zakon o lokalnoj samoupravi, „Sl. Glasnik RS”, br. 129/2007 i 83/2014 - dr. Zakon, http://www.paragraf.rs/propisi/zakon_o_lokalnoj_samoupravi.html, Zakon o zaštiti prava..., Уcmaв..., Mustafa: tražićemo albansku zastawu milion puta ako treba, N1, 28. 11. 2014, http://rs.n1info. com/a15591/Vesti/Mustafa-Trazicemo-albansku-zastavu-milion-puta-ako-treba.html (dostęp 11. 04. 2016 r.). 
stwo - mniejszości (ujęcie wertykalne) oraz mniejszość - mniejszość (ujęcie horyzontalne). Przedstawiając rolę mniejszości w polityce etnicznej Republiki Serbii, niezbędne jest ukazanie elementu aktywności partyjnej, który jednak, jak zostanie wykazane poniżej, może być niezgodny z rzeczywistym obrazem etnicznej polityki państwowej, szczególnie na poziomie lokalnym. Ze względu na temat artykułu udział partii mniejszościowych na scenie politycznej Serbii zostanie przedstawiony jedynie w sposób ogólny. Po roku 2009 działalność mniejszościowych ugrupowań politycznych, w wyniku reformy dotyczącej utworzenia i rejestracji partii, była trudniejsza niż wcześniej, co wynikało z obowiązku ponownej rejestracji ugrupowania przy konieczności uzyskania 10 tysięcy podpisów. To zmieniło dotychczasowy pejzaż polityczny mniejszości, które i tak po tej dacie posiadały aż 42 partie (na 72 ugrupowania polityczne w Serbii w ogóle) ${ }^{20}$.

Po ostatnich wyborach powszechnych w kwietniu 2016 r. na 12 partii i koalicji w parlamencie obecne są cztery ugrupowania mniejszościowe (SVM, SDA, BDZ, PZDD - to o jedno więcej niż w wyborach w 2014 r.), zaś dwie wchodzą w skład koalicji (SDP w sojuszu z SNS i LSV) ${ }^{21}$. Niemniej ten wieloetniczny obraz parlamentu zakłóca proporcja rozłożenia mandatów, ponieważ ugrupowanie rządzące ma większość parlamentarną, przy której reprezentacja partii mniejszościowych oraz koalicji wygląda po prostu symbolicznie. Takie wrażenie dodatkowo potęguje fakt, że przedstawiciele mniejszości zasiadający we władzach szczebla lokalnego są oponentami tych zasiadających w Parlamencie Narodowym Serbii, o czym mowa będzie poniżej.

\subsection{Autonomiczna Prowincja Wojwodina}

Dobrym przykładem powyższego, zwłaszcza w ostatnich latach, jest Wojwodina, najbardziej rozwinięty region Republiki Serbii, uczestniczący w międzynarodowych projektach rozwojowych (np. z zakresu równouprawnienia płci czy gospodarki), które były uznane za najlepsze w regionie przez ONZ i UE. W rozstrzygnięciach administracyjnych może być on przykładem wielu pozytywnych rozwiązań, które temu wieloetnicznemu obszarowi pozwalały uniknąć relatywnie głębszych konfliktów, w porównaniu np. z San-

${ }^{20}$ Zob. więcej na ten temat: D. Miku cka-W ój tow ic z, Działalność partii mniejszości narodowych w Republice Serbii w latach 1990-2008, [w:] Annales Universitatis Paedagogicae Cracoviensis. Studia Politologica XI (2013), red. K. Sobolewska-Myślik, Wydawnictwo Naukowe UP, Folia 138, Kraków 2013 , s. 91.

${ }^{21}$ W przedterminowych wyborach parlamentarnych (kwiecień 2016 r.) ponownie zwyciężyła koalicja premiera Aleksandra Vučicia - Serbia Zwycięża, w której 131 mandatów otrzymała Serbska Partia Postępowa (SNS), 30 - Serbska Partia Socjalistyczna (SPS), 21 - Serbska Partia Radykalna, po 16 - Partia Demokratyczna (DS) i ugrupowanie Dosyć (Dosta je bilo), 13 - koalicja Partii Liberalno-Demokratycznej - Ligi Socjaldemokratów Wojwodiny - Serbskiej Partii Demokratycznej (LDP-LSV-SDS), 13 - Partia Demokratyczna Serbii Dveri (DSS-Dveri), 4 - Związek Węgrów Wojwodińskich (SVM - o dwa mniej niż w wyborach w 2014 r.), 2 - Boszniacka Wspólnota Demokratyczna (BDZ), 2 - Partia Akcji Demokratycznej (SDA - w 2014 r. miała 3 mandaty), 1 - Zieloni i 1 - albański Ruch dla Działalności Demokratycznej (PZDD z tą różnicą, że Rize Halimiego zastąpiła Ardita Sinani). W poprzednich, również przedterminowych wyborach LSV było w koalicji z Nową Partią Demokratyczną - Zieloni i Razem dla Serbii. Tym razem do parlamentu nie weszło ani jedno ugrupowanie romskie (w 2014 r. było również w koalicji z Nową Partią Demokratyczną) oraz Związek Wojwodińskich Węgrów - Ištvana Pastora (w 2014 r. miał 6 mandatów), Број добијених мандата, Народна Скупштина Републике Србије, http://www.parlament.gov.rs./ народна-скупштина/ народна-скупштина-убројкама.1734.html, Najnoviji rezulatati parlamentarnih izbora, Eizbori, http://eizbori.com/rezultati-izbora-2016-srbija/ (dostęp 11. 04. 2016 r.). 
dżakiem czy południową Serbią. Obszar autonomiczny zajmuje powierzchnię $21506 \mathrm{~km}^{2}$ i zamieszkuje go, według spisu powszechnego z 2011 r., 1931809 mieszkańców, co stanowi prawie $27 \%$ całej populacji Republiki Serbii ${ }^{22}$.

Na obszarze Wojwodiny dominują liczebnie dwie narodowości - Serbowie i Węgrzy, którzy mają absolutną większość w sześciu gminach na północy prowincji, ale zamieszkują także 25 innych gmin ${ }^{23}$. I tak, jeśli na 169 gmin w Serbii 68 jest wieloetnicznych, to tylko na obszarze Wojwodiny znajduje się ich 41 . Na 45 wojwodińskich gmin wyłącznie w siedmiu serbski pozostawał jedynym językiem urzędowym (Inđija, Irig, Opovo, Pančevo, Pećinci, Ruma i Sremskie Karłowice), przy czym zgodnie z uchwałą władz APW o działalności administracji urzędnicy mają obowiązek znać język serbski, a użycie języków mniejszości określa akt o wewnętrznej organizacji struktur i miejsc pracy (art. 26) ${ }^{24}$. Jednak regulacje prawne władz serbskich i wojwodińskich wychodzą naprzeciw mniejszościom i racjonalizują użycie języków w codziennym stosowaniu, np. w okręgach, gdzie nie są spełnione warunki, by język mniejszości był językiem urzędowym, dopuszcza się stosowanie go na innych zasadach ${ }^{25}$.

AP Wojwodina posiada odrębny status, regulowany zarówno w Konstytucji Serbii (w art. 183-187), jak i w Statucie, czyli najwyższym akcie prawnym tej autonomii. Konstytucja reguluje również strukturę instytucjonalną władz wojwodińskich (art. 180) oraz zakres kompetencji regionu (art. 183), dodatkowo określony w Statucie Wojwodiny (art. 26-28). Najwyższym organem APW jest parlament (skupština), którego kadencja wynosi cztery lata. Wojwodina jako obszar autonomiczny dysponuje własnymi źródłami dochodu, z których finansuje swoją działalność, a jej rodzaj i rozmiar również są regulowane przez prawo. Jednak konstytucja podkreśla, że budżet APW powinien wynosić co najmniej 7\% budżetu Republiki Serbii (art. 184) ${ }^{26}$.

22 AP Wojwodinę zamieszkują następujące narody i grupy etniczne: Serbowie (1 289 635), Węgrzy (251 136), następnie Słowacy (50 321), Chorwaci (47 033), Romowie (42 391), Rumuni (25 410), Czarnogórcy (22 141), Buniewcy (16 469), Rusini (13 928), Jugosłowianie (12 176), Macedończycy (10 392), Ukraińcy (4202), Muzułmanie (3360), Niemcy (3272), Albańczycy (2251), Słoweńcy (1815), Bułgarzy (1489), Goranie (1179), Rosjanie (1173), Boszniacy (780), Wołosi (170) i inni (6710). 81018 osób odmówiło ujawnienia swojej przynależności narodowej lub etnicznej, zaś 28567 określiło ją jako regionalna. Z kolei 14791 osób nie było w stanie określić swojej tożsamości narodowej. Łącznie na obszarze Wojwodiny występuje ponad 26 mniejszości narodowych i etnicznych, Статут Аутономне Покрајине..., Попис становништва..., s. 20 і 21.

${ }^{23}$ N. Goj k ović, op. cit., s. 5; Nacionalne manjine. Činjenice o Srbiji, Web-site Vlade Republike Srbije, http://www.arhiva.srbija.gov.rs/cms/view.php?id=1019n (dostęp 4. 04. 2016 r.).

${ }^{24}$ Zob. też art. 16-20 Zakon o službenoj upotrebi jezika i pisama, ,Službeni glasnik Republike Srbije”, br. 45/91, 53/93, 67/93, 48/94, 101/2005, 30/2010, http://www.paragraf.rs/propisi/zakon_o_sluzbenoj_upotrebi_jezika_i_pisama.html, Pokrajinska skupštinska odluka o pokrajinskoj upravi, „Službeni list AP Vojvodine”, br. 4/2010, 4/2011, http://www.ljudskiresursi.vojvodina.gov.rs/downloads/9.\%20Pokrajinska\%20skupstinska\%20 odluka\%20o\%20pokrajinskoj\%20upravi.pdf, O bližem uređivanju pojedinih pitanja službene upotrebe jezika i pisama nacionalnih manjina na teritoriji Autonomne Pokrajine Vojvodine, „Sl. list AP Vojvodine”, br. 8/2003, 9/2003 - ispr. i 18/2009 - promena naziva akta, http://www.hnv.org.rs/docs/POKRAJINSKA\%20Odluka\%20 jezik.pdf (dostęp 11. 04. 2016 r.), N. Gojk ović, op. cit., s. 8.

${ }^{25} \mathrm{Na}$ ten temat oraz języków mniejszości na obszarze Republiki Serbii zob. więcej: Zakon o službenoj upotrebi...; M. Kor z e ni ew sk a-W is zn i e w ska, Serbskie aspiracje do struktur europejskich. Sytuacja mniejszości narodowych i etnicznych w Autonomicznej Prowincji Wojwodiny ze szczególnym uwzględnieniem systemu kształcenia, [w:] Slavia Meridionalis, t. XII, red. Lilla Moroz-Grzelak, wyd. Slawistyczny Ośrodek Wydawniczy, Warszawa 2012, s. 193 i następne.

26 Усmaв... 


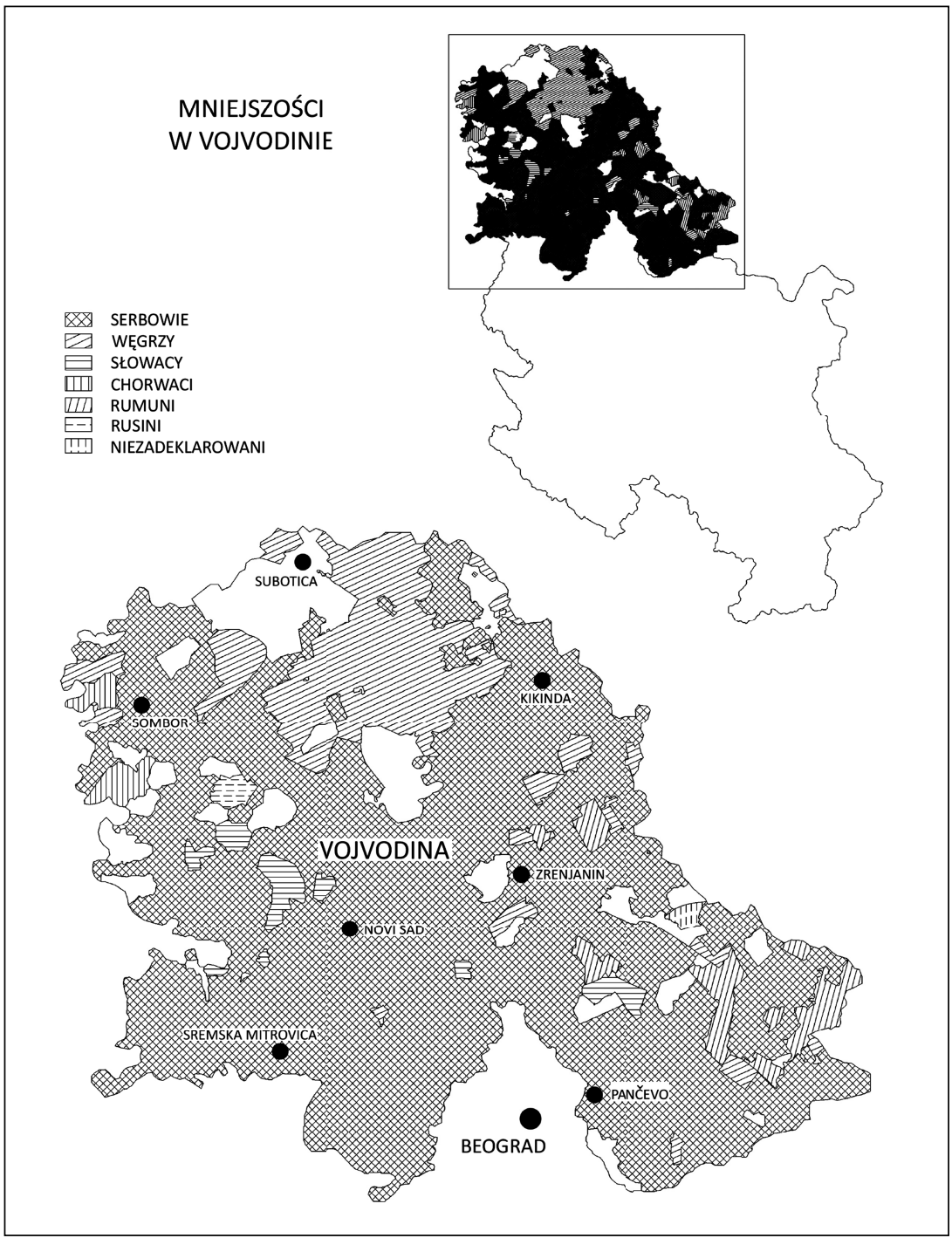

Mapa 1. Na mapie zaznaczono obszary, na których mniejszości, oznaczone zgodnie z legendą, stanowią powyżej 50 \% mieszkańców (wykonanie: Piotr Nowaczyński).

W skład obecnego Parlamentu APW wchodzi 17 ugrupowań oraz jedna osoba niezrzeszona, z czego większość mandatów posiadają Serbowie z tradycyjnych ugrupowań, których historia sięga jeszcze lat $90 . \mathrm{XX} \mathrm{w.}{ }^{27}$ Obraz rządu zdecydowanie nie odzwierciedla

${ }^{27}$ Należy zaznaczyć, że aktualnie analiza składu etnicznego sprawia dużą trudność, podobnie jak np. analizy struktur zatrudnienia według klucza narodowego ze względu na politykę państwa serbskiego, które pozostawia dowolność w deklaracjach narodowych, zaś te informacje traktuje jako dane wrażliwe. Niejednokrotnie organy administracji państwowej nie zgadzają się na udostępnianie dokumentów, więc struktury narodowościo- 
wieloetnicznej struktury i tym samym nie jest w oczach mniejszości reprezentatywny, co stwierdził Ištvan Pastor - przewodniczący Związku Węgrów Wojwodińskich ${ }^{28}$. Tymczasem nadzieje wiąże się ze zmianą ordynacji wyborczej podczas wyborów lokalnych (również na obszarze APW), które odbędą się w sierpniu 2016 r. Dotychczasowa ordynacja mieszana (większościowo-proporcjonalna) pozwała na utrzymanie władzy po roku 2000 przez tę samą konfigurację ugrupowań politycznych. Należy dodać, że jak dotychczas ani Konstytucja, ani Statut nie przewidywały parytetów, jeśli chodziło o reprezentację mniejszości we władzach APW, przy zachowanym progu 5\% uzyskania ważnych głosów w wyborach, który to warunek znacznie redukuje liczbę partii, wchodzących w struktury zarówno władz Wojwodiny, jak i Parlamentu Serbii ${ }^{29}$.

\subsection{Sandżak}

Region Sandżaka pozostaje obszarem, dla którego autonomia wojwodińska jest wzorem pożądanego statusu i zakresu samodzielności. Region ten jest obszarem o ponad połowę mniejszym od APW - $8867 \mathrm{~km}^{2}$, dodatkowo położonym aktualnie na terytorium dwóch państw: Serbii oraz Czarnogóry, przy czym granica międzypaństwowa dzieli sandžackie terytorium w zasadzie na pół ${ }^{30}$. Według spisu powszechnego z 2011 r. narodowość boszniacką w Republice Serbii zadeklarowało 145270 osób $(2,02 \%)^{31}$, co plasuje tę

wej można jedynie się domyślać $\mathrm{z}$ brzmienia nazwisk (choć ta metoda jest $\mathrm{z}$ wielu względów nieodpowiednia), zaś w powyższym przypadku o ugrupowaniu narodowym świadczy jego nazwa. Na tę problematyczną sytuację wskazują osoby prowadzące również badania terenowe. Patrząc na skład parlamentu wojwodińskiego, należy stwierdzić, że na 120 mandatów aż 95 jest w rękach ugrupowań serbskich, 7 należy do Węgrów (Związek Wojwodińskich Węgrów), 1 do Chorwatów (Demokratyczny Związek Chorwatów Wojwodiny), 1 SDP - Rasima Ljajicia, 2 do Trzeciej Serbii, 10 ma Liga Socjaldemokratów Wojwodiny (obie partie są wieloetniczne) oraz 1 - Zieloni - społeczna sprawiedliwość (funkcjonująca wcześniej pod nazwą: Zjednoczeni emeryci i społeczna sprawiedliwość), Посланичке груnе, Скупштина Аутономне покрајине Војводине, Република Србија Аутономна покрајина Војводина, http://www.skupstinavojvodine.gov.rs/Strana.aspx?s=poslanickegrupe\#По сланици који нису чланови посланичких група, Р. O b ra d o v i ć, Između demokratskog i etničkog principa, „Vreme”, nr 1060, 28. 08. 2011, http://www.vreme.com/cms/view.php?id=988099 (dostęp 8. 02.2016 r.).

${ }^{28}$ Na temat składu rządu zob. Članovi Pokrajinske Vlade, Republika Srbija. Autonomna Pokrajina Vojvodina, http://www.vojvodina.gov.rs/sr/\%D1\%87\%D0\%BB\%D0\%B0\%D0\%BD $\% \mathrm{D} 0 \% \mathrm{BE} \% \mathrm{D} 0 \% \mathrm{~B} 2 \% \mathrm{D} 0 \% \mathrm{~B} 8-$ -\%D0\%BF\%D0\%BE\%D0\%BA\%D1\%80\%D0\%B0\%D1\%98\%D0\%B8\%D0\%BD\%D1\%81\%D0\%BA\%D0\%B5-\%D0\%B2\%D0\%BB\%D0\%B0\%D0\%B4\%D0\%B5\# (dostęp 11. 04. 2016 r.).

${ }^{29}$ Więcej na temat działalności partii mniejszościowych zob. D. Mikucka-Wójtowicz, op. cit., s. 88 i następne.

${ }^{30} \mathrm{Na}$ terytorium Serbii znajduje się $4504 \mathrm{~km}^{2}$, zaś na terytorium Czarnogóry $3905 \mathrm{~km}^{2}$.

${ }^{31}$ Ta liczba zwiększyła się w stosunku do spisu z 2002 r., w którym Boszniacy stanowili 136 087, ale pozostała wciąż mniejsza w stosunku do spisu z 1991 r., według którego terytorium całkowitego obszaru Sandžaka zamieszkiwało 440000 osób, z czego Boszniacy stanowili 253 000, a Serbowie i Czarnogórcy 187 000, przy czym na obszarze serbskiej części - 180222 . Z tym że liczba ta dotyczyła osób zadeklarowanych jako Muzułmanie (pod taką nazwą naród boszniacki funkcjonował do 1993 r.). Równocześnie należy zauważyć, że narodowość muzułmańską zadeklarowało w 2011 r. 22301 osób (są to osoby, które nie zmieniły nazwy narodowej z Muzułmanina na Boszniaka), Попис становништва..., s. 14 i 15; G. B a š ić, Položaj Bošnjaka u Sandžaku, wyd. Centar za antiratnu akciju Mir, Beograd 2002, s. 14; Sandžak, Bošnjačko nacionalno vijeće, http://www.bnv.org.rs/ostalo/sandzak/, (dostęp 11. 04. 2016 r.).

O ewolucji nazwy narodowej Muzułmanów i Boszniaków zob.: M. Korzeniew ska-Wis zni ew ska, Obraz relacji serbsko-boszniackich na przykładzie Sandžaku w pierwszej dekadzie XXI w., [w:] Bałkany Zachodnie między przeszłościq a przyszłościq, red. P. Chmielewski, S. L. Szczesio, Łódź 2013, s. 493 i 494. 
mniejszość pod względem liczebności w państwie na drugim miejscu, zaraz po Węgrach. Przy czym obszar Sandżaka zamieszkuje 142767 osób, czyli ponad 98\% przedstawicieli tej mniejszości ${ }^{32}$.

Ambicje związane z dążeniami do uzyskania większej niezależności od Belgradu sięgały początku lat 90 . XX w. oraz rozpadu politycznego Socjalistycznej Federacyjnej Republiki Jugosławii. Boszniacy, pod przywództwem Sulejmana Ugljanina, dążyli do uzyskania autonomii, jednak wszelkie koncepcje separatystyczne były wówczas zwalczane przez Belgrad, czego dowodem było faktyczne zniesienie serbskich autonomii w tamtym czasie (Kosowa i Wojwodiny). Ten stan trwał do końca lat 90. XX w., kiedy to koncepcja autonomii powróciła w 1999 r. i po przemianach politycznych w 2000 r. przybrała zinstytucjonalizowaną formę w postaci Boszniackiej Rady Narodowej (BRN) w Serbii i Czarnogórze, która zastąpiła działającą od pierwszej połowy lat 90. XX w. Muzułmańską Radę Narodową Sandżaka. BRN działała od roku 2003, zaś jej aktywność skupiała się na obszarze mniejszościowej autonomii kulturalnej, medialnej i językowej, przy czym instytucja za przełomowy uznała rok 2009 i nową ustawę dotyczącą mniejszości w Republice Serbii, która przyniosła Statut Boszniackiej Rady Narodowej (przyjęty w 2009 r. i ostatni raz nowelizowany w 2015 r.) - jako najwyższego aktu BRN ${ }^{33}$. Organem wykonawczym BRN jest Komitet Wykonawczy, któremu podlega pięć Komisji o wyspecjalizowanym zakresie kompetencji (Komisja ds. kształcenia w języku bośniackim; Komisja ds. kultury; Komisja ds. stosowania bośniackiego jako języka urzędowego w mowie i piśmie; Komisja ds. informacji w języku bośniackim; Komisja ds. kontroli i nadzoru realizacji praw Boszniaków w Republice Serbii) ${ }^{34}$.

Po 2010 r. doszło w BRN do wewnętrznych konfliktów na tle politycznym, ale i kontrowersji na linii BRN - władze Serbii, których interwencje w wybory do Rady potraktowane zostały jako ingerencja w sprawy mniejszościowe i łamanie praw Boszniaków. To sparaliżowało działalność BRN na jakiś $\operatorname{czas}^{35}$; w konsekwencji relacje z Belgradem ustabilizowały się dopiero od bieżącej kadencji ${ }^{36}$, w której większość mandatów posiada ugrupowanie Sulejmana Ugljanina, a więc polityka współpracującego - podobnie jak Rasim Ljajić - od lat z władzami Serbii. Polepszenie stosunków z władzami centralnymi nie przełożyło się na wzrost popularności wśród samych Boszniaków, którzy oceniają Radę jako instytucję niewydolną, bez transparentnej polityki informacyjnej (nie ma żadnych

32 Pozostały odsetek zamieszkuje w największym stopniu obszar Belgradu oraz Wojwodiny.

${ }^{33} \mathrm{O}$ Vij e ć u, Bošnjačko nacionalno vijeće, http://www.bnv.org.rs/o-nama/ (dostęp 11. 04. 2016 r.).

${ }^{34}$ Więcej na temat organizacji Boszniackiej Rady Narodowej oraz zakresu jej kompetencji zob. Statut Bošnjačkog Nacionalnog Vijeća, „Službeni glasnik RS” br. 72/2009, 20/2014 - odluka US i 55/2014, http:// www.bnv.org.rs/wp-content/uploads/2015/06/1.02.-2015-05-Statut-Bo\%C5\%A1nja\%C4\%8Dkog-nacionalnogvije\%C4\%87a.pdf, Odbori, Bošnjačko nacionalno vijeće, http://www.bnv.org.rs/tijela-bnv/odbori/ (dostęp 10. 04. 2016 r.), M. S e ro ka, Serbska Cerkiew Prawosławna wobec konfliktów narodowościowych w bytej Jugosławii, [w:] My już jesteśmy zjedzeni...Rola i znaczenie prawosławia $w$ konflikcie etnicznym $w$ Dolinie Preszewa, red. R. Zenderowski, Wydawnictwo Instytutu Politologii Uniwersytetu Kardynała Wyszyńskiego w Warszawie, Warszawa 2012, s. 256.

${ }^{35}$ Zob. więcej na ten temat: M. Kor zeniew ska-Wis zniew s ka, Obraz relacji..., s. 499.

${ }^{36}$ Kadencje są czteroletnie, aktualna trwa od listopada 2014 r., zaś większość w Radzie ma Lista dla Boszniackiej Jedności Sulejmana Ugljanina, O Vijeću, Bošnjačko nacionalno vijeće, http://www.bnv.org.rs/o-nama/ (dostęp 11. 04. 2016 r.), M. S e ro k a, Serbska Cerkiew Prawosławna wobec konfliktów narodowościowych w bylej Jugosławii, [w:] My już jesteśmy zjedzeni...Rola i znaczenie prawosławia w konflikcie etnicznym w Dolinie Preszewa, s. 257. 


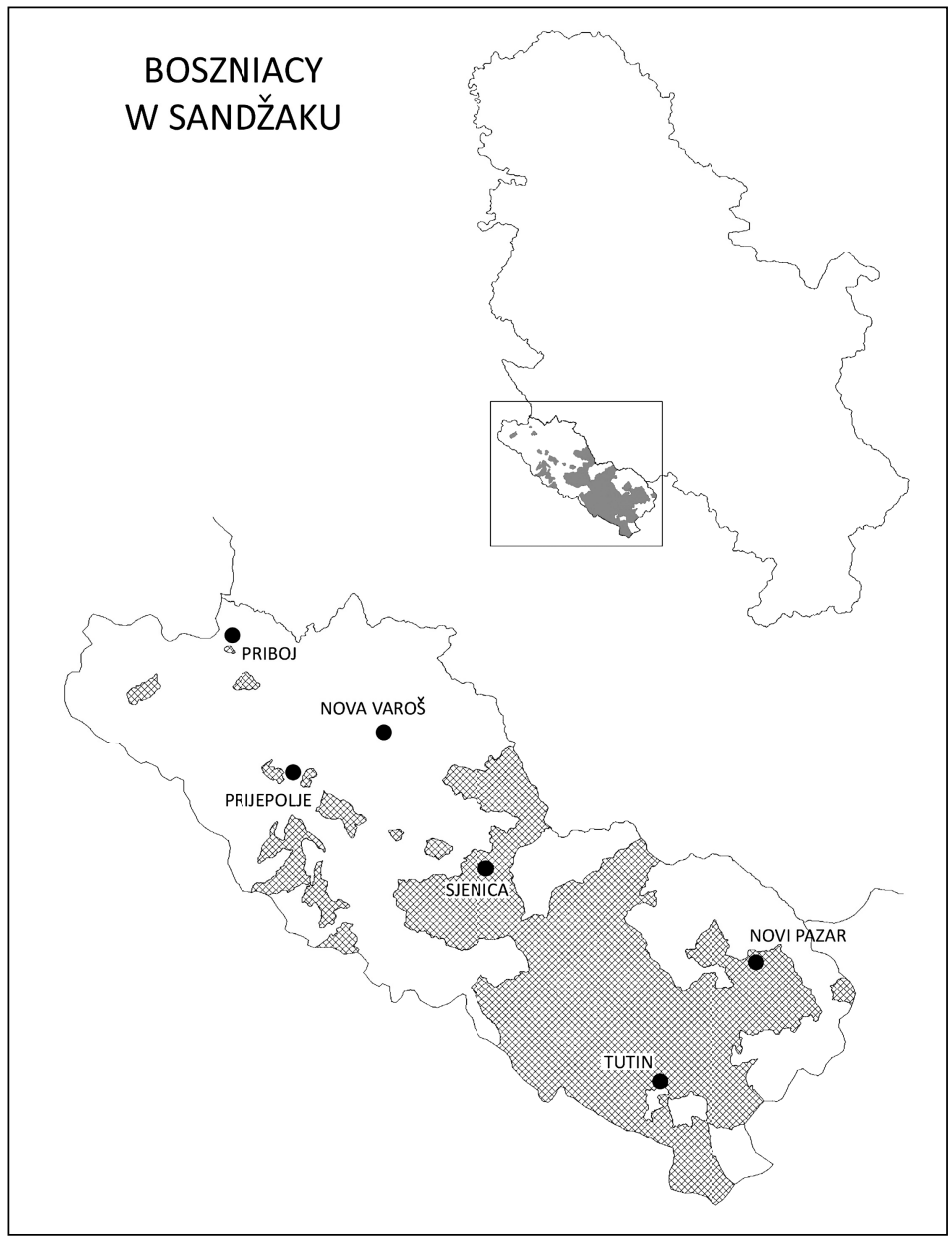

Mapa 2. Rozmieszczenie ludności boszniackiej w Sandżaku (wykonanie Piotr Nowaczyński).

kanałów telewizyjnych, sporadycznie wydawane jest czasopismo) i niemającą realnego wpływu na poprawę boszniackiej społeczności. Samo BRN broni swojego wizerunku stwierdzeniem o braku środków finansowych na realizację planów ${ }^{37}$.

\subsection{Preszewo, Bujanovac, Medveđa}

W przypadku mniejszości albańskiej aktualna sytuacja wiąże się z wydarzeniami przełomu XX i XXI w., kiedy to Kosowo w wyniku wojny między armią serbską i bojówkami paramilitarnymi UÇK, wspartymi przez NATO, zostało wyłączone spod jurys-

${ }^{37}$ E. El e s k o vi ć, Uloga i dostignuća BNV u Sandžaku, „Dana”, 31. 01. 2016, http://www.danas.rs/dodaci/sandzak/uloga_i_dostignuca_bnv_u_sandzaku.42.html?news_id=315192 (dostęp 9. 04. 2016 r.). 
dykcji Belgradu, stając się protektoratem międzynarodowym. Dla Albańczyków było to uzyskanie niepodległości od państwa serbskiego (którą faktycznie Priština proklamowała na początku 2008 r.), zaś walki przeniosły się na południe Serbii, na obszary zamieszkałe przez ludność albańską, spośród której utworzono, przy wsparciu bojowników UÇK, UÇPMB (Armia Wyzwoleńcza Preszewa, Medveđi i Bujanovca). Celem stało się połączenie administracyjne z Kosowem i wyłączenie spod jurysdykcji Serbów również tych obszarów. Konflikt zbrojny trwał do maja 2001 r. ${ }^{38}$ Po jego zakończeniu część społeczności albańskiej nie zrezygnowała z planów połączenia się z Kosowem, zaś druga część była gotowa na podjęcie współpracy z władzami serbskimi. Już wcześniej region należał do najmniej rozwiniętych obszarów państwa, zaś po 2001 r. doszły dodatkowo zniszczenia wojenne i wyłączenie części terytorium z użytku aż do czasu rozminowania, które trwa do dziś. Trudności i specyfika terytorium przyczyniły się do utworzenia przez władze w Belgradzie ciała koordynacyjnego Rządu Republiki Serbii dla gmin Preszewo, Bujanovac i Medveđa, zamieszkałych przez mniejszość albańską ${ }^{39}$. Jego działalność obejmuje płaszczyznę: ekonomiczno-infrastrukturalną, oświatową, socjalną, współpracę z mniejszościami i międzynarodowymi partnerami, media oraz przeprowadzanie konkursów związanych z dofinansowaniem różnej działalności ${ }^{40}$. Organ ten został powołany w grudniu 2000 r., jednak działalność w obecnym zakresie podjął dopiero po 2009 r. ${ }^{41}$, co było związane zarówno w uchwaleniem nowej ustawy o mniejszościach, jak i powstającymi dzięki niej związkami mniejszościowymi.

Sami Albańczycy powołali w 2010 r., zgodnie z przysługującym im prawem, Narodową Radę Albańczyków, której władze wybierane są w demokratyczny sposób w ramach społeczności albańskiej. Organ ten miał na celu integrację społeczności albańskiej z serbską poprzez włączanie Albańczyków w działalność państwową, przyspieszenie dialogu między społecznością serbską i albańską oraz rozwijanie działalności przedstawicieli ludności albańskiej w lokalnych instytucjach. Według serbskich opinii organ ten

${ }^{38}$ Konflikt przeniósł się na obszar Macedonii w 2001 r., gdzie eskalował już wcześniej. Więcej na temat powyższego oraz macedońskiego konfliktu zob. I. S taw o w y-Kaw ka, Albańczycy w Macedonii, Kraków 2014, s. 287 i następne; A. Krza k, Assymetry of the Albanian-Macedonian Military Conflict in 2001. Military Characteristics of the Fight in the Regions of Tetovo, Kumanovo, Aračinovo and Vaksince, [w:] Macedonia in $20^{\text {th }}$ and $21^{\text {st }}$ century, „Politeja” nr 4(30), 2014, red. M. K or zen i ew s k a-W is z n i ew s ka, s. 299; M. S ty rc zula, Konflikt serbsko-albański w tzw. Dolinie Preszewa i Miedwiedzi, [w:] My już jesteśmy zjedzeni...Rola i znaczenie prawosławia $w$ konflikcie etnicznym $w$ Dolinie Preszewa, s. 326 i następne.

39 Według spisu powszechnego z 2011 r. Preszewo miało zamieszkiwać zaledwie 3080 osób, w tym 416 Albańczyków. W tym przypadku bliższe rzeczywistości dane zawierają statystyki z 2002 r., według których liczba Albańczyków wynosiła 31098 na 34904 mieszkańców (89, 09\%). W Bujanovcu na 18067 mieszkańców narodowość albańską zadeklarowały zaledwie 244 osoby, co daje 1, 35\%, podczas gdy w 2002 r. na 43302 mieszkańców narodowość tę zadeklarowało 23681 (54,68\%) osób. W przypadku Medveđi na 7438 - 527, co daje 7,8\%, podczas gdy liczbę ludności tej miejscowości szacuje się na ok. 25\%, co odpowiadałoby spisowi z 2002 r., w którym na 10760 mieszkańców Albańczycy stanowili 2816, co daje 26,17\%. Przy czym w spisie z 2011 r. zaznaczono, że dane odnoszą się wyłącznie do osób uczestniczących w spisie. Попис становништва..., s. 76 і 86, Коначни резултати пописа 2002..., s. 12.

40 Активности, Координационо тело Владе Републике Србије за општине Прешево, Бујановац и Медвеђа, http://www.kt.gov.rs/cr/articles/aktivnosti/ (dostęp 12. 04. 2016 r.).

${ }^{41} \mathrm{Na}$ ten temat zob.: Serbia: Maintaining Peace In Preshevo Valley. Europe Report $N^{\circ} 186$ - 16 October 2007, International Crisis Group, http://www.crisisgroup.org/ /media/Files/europe/186_serbia_maintaining_peace_in_the_presevo_valley.pdf(dostęp 5.04.2016 r.) 


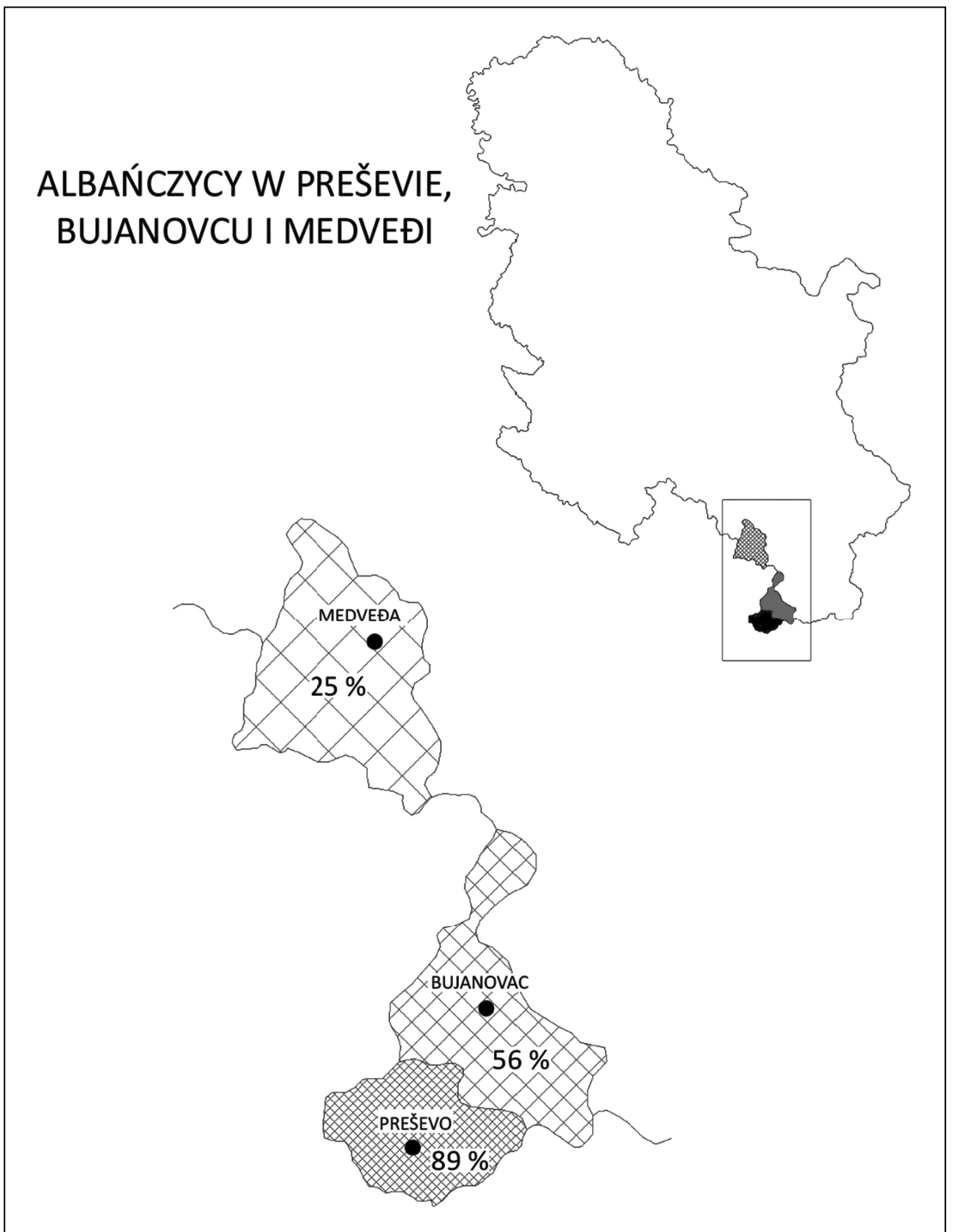

Mapa 3. Mapa przedstawia szacowany odsetek ludności albańskiej w trzech gminach na południu Serbii (wykonanie Piotr Nowaczyński).

aktualnie współpracuje skutecznie z ciałem koordynacyjnym np. w dziedzinie oświaty (w tym w zakresie sprowadzania, tłumaczenia i rozpowszechniania podręczników w języku albańskim) $)^{42}$.

${ }^{42}$ Bojkot nastave zbog nedostatka udžbenika na albanskom jeziku, Južne Vesti, 27. 10. 2015, http://www. juznevesti.com/Drushtvo/Bojkot-nastave-zbog-nedostatka-udzbenika-na-albanskom-jeziku.sr.html, Izbori 2014. za nacjonalne savete nacionalnih manjina, Minority News, http://izbori.minoritynews.rs/nacionalni-savet-albanske-nacionalne-manjine (dostęp 30. 04. 2016 r.). 


\subsection{Specyfika polityki etnicznej charakteryzowanych regionów}

Mimo rzeczywistych skutecznych narządzi polityki etnicznej, którą zapewnia państwo serbskie, a które zostały krótko scharakteryzowane powyżej, mamy do czynienia na terytorium tych regionów z rodzajem relacji o charakterze nieustającego sporu etnicznego w wymiarze wertykalnym oraz horyzontalnym. Wertykalnym - a więc na linii państwo mniejszość etniczna (i ten spór, a nawet konflikt dotyczy zasadniczo zarówno przypadku Sandżaka, jak i Preszewa, Medveđi oraz Bujanovca), jak i między samymi grupami etnicznymi (a nawet w ich obrębie), w którym to modelu (horyzontalnym) państwo powinno odgrywać rolę bezstronnego arbitra (model tych relacji odnosi się z kolei do wszystkich opisywanych powyżej obszarów ${ }^{43}$. Dokonując analizy etnopolityki Serbii w kontekście relacji etnicznych wobec tych regionów, ujęcie wertykalne można zaprezentować w dwojaki sposób. Pierwsze z nich wskazuje na opresyjność państwa serbskiego wobec mniejszości, której pobratymcy, ale i ona sama, w niedalekiej przeszłości byli stroną konfliktu zbrojnego, antagonizującą z Serbami ${ }^{44}$, zaś pamięć o tych wydarzeniach uniemożliwiała normalizację stosunków w pierwszej dekadzie XXI w., czego pokłosie występuje do dziś. Może się to uzewnętrzniać w niechęci władz państwowych do respektowania praw mniejszościowych, które wykraczały poza regulowaną prawem konieczność, co mogło przejawiać się np. niedostatecznym rozwojem ekonomicznym danego regionu, do czego nie zobowiązywało prawo, a co łatwo można było usprawiedliwić brakiem funduszy na takie przedsięwzięcia z powodu złej kondycji gospodarczej kraju w pierwszym dziesięcioleciu XXI w. ${ }^{45}$

Drugie ujęcie relacji wertykalnych zakłada obstrukcjonizm przywódców społeczności etnicznych wobec współpracy z rządem centralnym w Belgradzie. Manifestuje się on w odrzucaniu działań politycznych lub innych inicjatyw władz centralnych w imię swoiście pojmowanej lojalności etnicznej, wykluczającej porozumienie z opresorem. Takim przykładem mógł być bojkot wyborów parlamentarnych przez Demokratyczną Partię Albańczyków ${ }^{46}$ w 2012 r. lub bojkot spisu powszechnego przez część społeczności boszniackiej w Sandżaku ze względu na brak formularzy bośniackojęzycznych ${ }^{47}$. Również takim przykładem mogła być odmowa współpracy z ciałem koordynującym przez Ragmiego

${ }^{43}$ A. Wi e r z b i c k i, Genetyczno-kulturowe podstawy etnopolityki. Perspektywa etnonacjonalistyczna, [w:] Polityka etniczna. Teorie, koncepcje, wyzwania, red. H. Chałupczak, R. Zenderowski, E. Pogorzała, T. Browarek, Wydawnictwo UMCS, Lublin 2015, s. 54.

${ }^{44}$ Serbowie kontra Boszniacy w Bośni i Hercegowinie, czy Serbowie kontra Albańczycy w Kosowie - oba kraje graniczą z Republiką Serbii.

${ }^{45} \mathrm{O}$ wieloaspektowym podłożu konfliktu serbsko-albańskiego w tamtym regionie zob. M. S e r o k a, Serbska Cerkiew Prawosławna wobec konfliktów narodowościowych w byłej Jugosławii, [w:] My już jesteśmy zjedzeni... Rola i znaczenie prawosławia w konflikcie etnicznym w Dolinie Preszewa, s. 257 i 274.

${ }^{46}$ Na czele Demokratycznej Partii Albańczyków stoi Ragmi Mustafa - obecny burmistrz Preševa.

47 Paradoksalnie, nawoływanie do boszniackiego bojkotu przez ich przywódców politycznych i duchowych zaowocowało tym, że według oficjalnego spisu przeprowadzonego w Republice Serbii w 2011 r. tę narodowość zadeklarowało więcej osób aniżeli w 2001 r. (145 278, podczas gdy w 2002 r. narodowość tę zadeklarowało 136 087). Faktycznego bojkotu dokonała z kolei ludność albańska, co można wywnioskować z podanych statystyk, według których w Republice Serbii aktualnie miałoby żyć zaledwie 5809 Albańczyków, podczas gdy według spisu z 2002 r. narodowość tę zadeklarowało 61647 osób. W oficjalnych dokumentach zaznaczono, że w gminie Preszewo oraz Bujanovac nie dokonano pełnego spisu, Попис становништва.., s. 14 i 18, zob. też M. S e r o k a, op. cit., s. 288. 
Mustafę, co usprawiedliwiał podpisaniem porozumienia o działalności przedstawicielstwa ciała koordynacyjnego w Preszewie z poprzednimi lokalnymi władzami (albańską konkurencyjną partią Ruch dla Działalności Demokratycznej Rizy Halimi), traktując ów akt jako indywidualne porozumienie między ówczesnymi władzami, a nie jako program dla południowej Serbii. Obawy władz serbskich wobec takiej postawy mogło dodatkowo wzmacniać stanowisko samych przywódców mniejszości etnicznych, którzy bojkotując wybory powszechne lub działalność władz centralnych w ogóle, wzmacniały równocześnie swoją pozycję w wymiarze lokalnym. Doprowadzało to do sytuacji, w której elektorat, wspierający tychże przywódców, jest przekonany o obstrukcjonizmie państwowym wobec ich praw mniejszościowych, których nie będą w stanie zapewnić - wraz z poprawą stopy życiowej - pojedynczy przedstawiciele w parlamencie, czy nawet rządzie Republiki Serbii, co miał potwierdzić cały okres, jaki upłynął od przemian politycznych w Serbii w 2000 r. Z tego powodu elektorat ten wspiera polityków bojkotujących wybory do centralnych władz państwowych, umacniając jednocześnie władzę na szczeblu lokalnym, realizowaną wśród mniejszości i dla mniejszości. Znamienny jest przykład Preszewa, którego albańskie władze nie są zainteresowane włączaniem Serbów w lokalne struktury administracji państwowej, uważając, że tysiącosobowa (ok. 8,5\%) społeczność serbska jest mało znaczącym odsetkiem ${ }^{48}$. Wzmacnianie władz na poziomie lokalnym może doprowadzić do stworzenia sytuacji, w której relacje między strukturami władzy nabiorą charakteru państwa w państwie, co może skutkować ewolucją separatyzmów, których tak bardzo obawiają się władze centralne wszystkich państw bałkańskich. W przypadku serbskim obawy te mają uzasadnienie. Według przewodniczącego ciała koordynacyjnego Zorana Stankovicia, mimo licznych regulacji prawnych dla tego regionu trudno o stosowanie przepisów ze względu na brak poszanowania dla prawa i nieprzestrzeganie prawodawstwa państwowego przez mniejszość albańską. Z kolei we wrześniu 2015 r. przedstawiciele pięciu ugrupowań albańskich powołali Stowarzyszenie Gmin Albańskich, co było odpowiedzią na utworzenie w ramach porozumienia brukselskiego między Prištiną a Belgradem Stowarzyszenia Gmin Serbskich w Kosowie. Zakładało ono szeroką autonomię dla serbskiej ludności z północy Kosowa, tak więc władze belgradzkie mogły mieć uzasadnione obawy, że albańska inicjatywa będzie dążyła do uzyskania analogicznego statusu. Nie można też zapominać, że autonomię tych gmin jeszcze przed 2009 r. postulował aktualnie współpracujący z władzami serbskimi Riza Halimi, czyli polityk uchodzący za bardziej umiarkowanego od chociażby Ragmiego Mustafy ${ }^{49}$.

W przypadku Boszniaków sandżackich obawy o powrót koncepcji separatystycznych nasiliły się na przełomie pierwszej i drugiej dekady XXI w., kiedy to znaczącą rolę w życiu politycznym i duchowym zaczął odgrywać Muamer Zukorlić - polityk, biznesmen i duchowny o bardzo krytycznym stanowisku wobec Belgradu, mający silne związki z duchowymi i politycznymi przywódcami w Bośni i Hercegowinie. Jego nie-

${ }^{48}$ Wprawdzie w sejmiku Preševa jest dwóch radnych Serbów, jednak żaden z nich nie należy do ugrupowania rządzącego, P. Obrad o vić, op. cit.

49 Зоран Станковић о ситуацији у опитинама Прешево, Бујановац и Медвеђа у 2013. Години, Координационо тело Владе Републике Србије за општине Прешево, Бујановац и Медвеђа, http://www.kt.gov. rs/cr/video/single/Ot6TKBaaffU/75/, Formirana zajednica albanskih opština, B92, 12. 09. 2015, http://www.b92. net/info/vesti/index.php?yyyy=2015\&mm=09\&dd=12\&nav_category=11\&nav_id=1038405, (dostęp 13. 2016 r.), M. Styrczula, op. cit., s. 354. 
zgoda na ingerencję władz belgradzkich w kwestie BRN spowodowała założenie przez niego Narodowej Rady Sandżaka jako alternatywnej wobec BRN instytucji, jednak brak legitymacji zarówno ze strony władz, jak i wsparcia wśród społeczności sandžackiej zmarginalizował jej znaczenie w Serbii. Na obawy władz serbskich mogą wpłynąć postulaty radykalniejszej części działaczy boszniackich, takich jak Džemail Suljević, który wystąpił z projektem niepodległej republiki Sandżaka, opartej na rzekomych projektach partyzantów titowskich jeszcze z okresu II wojny światowej. Na rozwój takich koncepcji z pewnością mają wpływ procesy separatystyczne regionu, takie jak proklamowanie jednostronnej niepodległości przez Kosowo w 2008 r., ale też plany, by w niedalekiej przyszłości ogłosić w Republice Serbskiej referendum niepodległościowe na temat odłączenia się od Bośni i Hercegowiny ${ }^{50}$.

Podstawowymi zarzutami, jakie się pojawiają w relacjach wertykalnych z obu stron, są ze strony mniejszościowej: dyskryminacja na skutek nieprzestrzegania praw, bądź utrudnianie mniejszościom ich realizowania i bierność państwa wobec złej sytuacji ekonomicznej regionów zamieszkałych przez te mniejszości (bieda, bezrobocie, brak infrastruktury). Z punktu widzenia władz serbskich problem ten wygląda inaczej. Poza ustawodawstwem, które przybliża standardy położenia mniejszości narodowych i etnicznych w Serbii do standardów unijnych, państwo angażuje się zarówno we współpracę, jak i rozwój zacofanych regionów. Przykładem na to mogą być wymienione regulacje prawne, obecność polityków muzułmańskich (boszniackich) w serbskim rządzie oraz parlamencie, respektowanie związków narodowych i ich udział w życiu publicznym Serbii oraz angażowanie inwestycji krajowych i zagranicznych $\mathrm{w}$ regionach zamieszkałych przez mniejszość boszniacką. Sandžackie miasta objęte są programami polityki zatrudnienia (w tym praktykami zawodowymi), realizowanymi przez serbskie władze oraz władze lokalne w Tutinie i miejscowości Bijelo Pole. Szeroko zakrojony program inwestycyjny oraz infrastrukturalny (a także inne, w tym oświatowe) prowadzi też ciało koordynujące dla południa Serbii, inwestując w ostatniej dekadzie miliony euro w ten region zarówno z środków budżetowych, jak i unijnej oraz pozaunijnej pomocy międzynarodowej, przy współpracy z instytucjami albańskimi, w tym Radą Narodową Albańczyków. Jednak, jak wskazał przewodniczący ciała koordynującego Zoran Stanković, przedstawiciele społeczności albańskiej w kontaktach zewnętrznych mówią mimo to o braku jakichkolwiek praw mniejszościowych im przysługujących ${ }^{51}$.

${ }^{50}$ Na jego temat zob. więcej: Muftija Sandžacki, Islamska Zajednica u Srbiji, http://mesihat.org/muftijstvo-sandzacko/muftija-sandzacki2/ (dostęp 11. 04. 2016 r.); M. Korzeniews ka-Wiszniewska, Położenie mniejszości muzułmańskiej w Republice Serbii po 2008 r. w kontekście serbskich aspiracji wstapienia do Unii Europejskiej, [w:] Problemy aksjologiczne w relacjach Unii Europejskiej z Batkanami, red. M. Babić, F. Gołembski, Warszawa 2012, s. 266.

${ }^{51}$ K. Mus ić, Smanjiti broj naposlenih, ali građani ne trpe, „Danas”, 4. 02. 2016, http://www.danas. rs/dodaci/sandzak/smanjiti_broj_zaposlenih_ali_da_gradjani_ne_trpe_.42.html?news_id=315456, S. Novosel, Smanjenje broja nezaposlenih, „Danas” 4. 02. 2016, http://www.danas.rs/dodaci/sandzak/smanjenje_broja_nezaposlenih.42.html?news_id=315462, Зоран Станковић о постигнутим резултатима и о ичиљу разговора са албанским лидерима, Координационо тело Владе Републике Србије за општине Прешево, Бујановац и Медвеђа, http://www.kt.gov.rs/cr/video/single/TwECbArGyMU/70/, Tokom ove godine odobrena 23 projekta, Vesti Istočne Srbije, 17. 04. 2011 r., http://www.istocnasrbija.com/majdanpek/danas-tokom-ove-godine-odobrena-23-projekta, Z. Mila d i n o vi ć, Odobreno 18 projekata za nezaposlene, Vesti.rs. 12. 04. 2011 r., http://www. vesti.rs/Hronika/Odobreno-18-projekata-za-nezaposlene.html, (dostęp 11. 02. 2016 r.). 
Duże znaczenie dla roli mniejszości w polityce etnicznej Serbii mają również relacje o wymiarze horyzontalnym, czyli stosunki pomiędzy samymi mniejszościami (grupami etnicznymi), przy tutejszym założeniu, że są to grupy o takim samym statusie prawnym oraz zakresie praw kolektywnych i indywidualnych. Uwzględniając analizowany w tym tekście przypadek, wykluczymy więc z tej grupy Serbów jako naród konstytucyjny (tytularny). Obraz standardowy otrzymamy wówczas jedynie w Wojwodinie, zaś w pozostałych przypadkach będzie on nieco odbiegał od klasycznego przykładu, ponieważ ma on miejsce między przedstawicielami tej samej grupy etnicznej, a linia podziału przebiega wzdłuż poglądów politycznych, które mogą mieć zasadniczy wpływ na zróżnicowanie położenia ludności $\mathrm{w}$ obrębie tej samej grupy etnicznej. $\mathrm{Z}$ takim podziałem mamy do czynienia zarówno w przypadku Boszniaków z Sandżaka, jak i Albańczyków z południa Serbii, co zostało już nadmienione powyżej. Linię tych podziałów wykreśla stosunek przedstawicieli grupy etnicznej do władz centralnych, współpraca z nią oraz ocena położenia przedstawicieli własnej grupy etnicznej (a także przyczyn tego stanu rzeczy).

W przypadku zarówno Boszniaków, jak i Albańczyków konflikt przebiega na linii: działacze polityczni, którzy chcą współpracować z władzami serbskimi, kontra działacze polityczni, którzy uważają serbskie władze za opresyjne i są zwolennikami uzyskania różnego stopnia niezależności od Belgradu. W tej sytuacji pojawia się stereotypowa ocena polityków współpracujących z władzami jako osób opłacanych przez władze, które powinny być pozbawione legitymacji do reprezentacji interesów mniejszości. Z kolei oponenci oceniani są jako działacze (ugrupowania) niezdolni do kompromisu, których radykalne cele wykluczają jakiekolwiek porozumienie z ośrodkami decyzyjnymi w skali kraju, co może utrzymać patową sytuację przez lata, jak pokazują przykłady Sandżaka i Doliny Preszewa sprzed 2009 r. Jednym z narzędzi walki politycznej, mającej zwiększyć liczbę zwolenników, jest odświeżanie wizerunku poprzez powoływanie do życia nowych instytucji, które mają przynieść skuteczną i pozytywną zmianę. W przypadku Sandżaka było to powołanie Narodowej Rady Sandżaka przez Zukorlicia czy też projekt niepodległościowy Džemaila Suljevicia. Ze strony społeczności albańskiej z południa Serbii może to być utworzenie Wspólnoty Gmin Albańskich, jako odpowiedzi na utworzenie w Kosowie Wspólnoty Gmin Serbskich, której to inicjatywy nie poparła część społeczności albańskiej, w tym Riza Halimi (który jednak nie odciął się ostatecznie od inicjatywy) ${ }^{52}$.

Na obszarze Wojwodiny możemy spotkać się z nieco bardziej klasycznym przykładem sporu etnicznego, jednak należy zaznaczyć, że w przypadku Wojwodiny konflikty na tle etnicznym są incydentalne, zwłaszcza w porównaniu z pozostałymi omawianymi obszarami. Przykładem może być incydent z 2011 r., kiedy to do 20 najwyższych organów państwowych Chorwacji i Serbii wpłyną list otwarty podpisany przez grupę 30 chorwackich intelektualistów z Suboticy, którzy domagali się poszanowania integralności Buniewców $w$ Wojwodinie. Ich zdaniem od 2004 roku władze serbskie prowadziły politykę wynarodowiania części chorwackiej mniejszości narodowej w Wojwodinie bądź też jej asymilacji. Ponadto w liście postawiono zarzuty ograniczania prawa Buniewców do kształcenia w ję-

${ }^{52}$ Formirana zajednica..., Džemail Suljević sanja „,Sandžak Republiku”, Vesti.rs, 16. 08. 2010, http://www. vesti.rs/Milorad-Dodik/DZEMAIL-SULJEVIC-SANJA-SANDZAK-REPUBLIKU.html, Sandžak traži , ,partizansku autonomiju", Vesti online, 9. 08. 2010, http://www.vesti-online.com/Vesti/Srbija/73585/Sandzak-trazi-partizansku-autonomiju (dostęp 11. 04. 2016 r.). 
zyku chorwackim i do stosowania ich języka w regionalnych mediach elektronicznych. Równocześnie podczas obrad Narodowego Związku Buniewców (NZB) stwierdzono, że to Chorwaci z Wojwodiny, nie zaś Serbowie, asymilowali tę mniejszość. NZB domagał się od stosownych organów państwowych pociągnięcia do odpowiedzialności wszystkich osób, które ów list podpisały, ponieważ miały być one odpowiedzialne za negowanie istnienia autochtonicznych Buniewców wbrew konstytucji i prawu Republiki Serbii ${ }^{53}$.

Dodatkowym elementem, który negatywnie wpływa na etniczne antagonizmy, jest polityka dezinformacji i trudno w tym przypadku jednoznacznie wskazać stronę odpowiedzialną zarówno na płaszczyźnie relacji wertykalnych, jak i horyzontalnych. Jako przykład można wskazać stanowisko Ragmiego Mustafy wobec organu koordynującego, którego pracę miał bojkotować - według opinii Rizy Halimiego, co zresztą potwierdzały słowa samego zainteresowanego. Jednocześnie w jego oficjalnym biogramie figurowało stwierdzenie, że dobrze współpracuje z tymże organem. Jako inny przykład można wskazać wyniki programu zatrudniania w sektorze państwowym w 2011 r., który mógł przynieść pozytywne skutki w postaci współpracy międzyetnicznej (integracji), zmniejszenia liczby bezrobotnych oraz poprawienia statystyk, jeśli chodziło o reprezentację mniejszości (w tym przypadku Albańczyków) pod względem zatrudnienia w sferze budżetowej. W wyniku rozpisania konkursów większość osób, które zatrudniono, stanowili Serbowie, przy czym nie zapełniono całej puli nowych miejsc pracy. Albańczycy jako przyczynę takiego stanu rzeczy podali brak odpowiedniej polityki informacyjnej na temat konkursów, zaś organizatorzy tychże, że kandydaci nie spełniali odpowiednich wymagań kwalifikacyjnych ${ }^{54}$.

W tym miejscu autorka chciałaby zwrócić uwagę na jeszcze jeden aspekt relacji w polityce etnicznej Republiki Serbii, również w ujęciu wertykalnym, a więc na linii państwo grupa etniczna, jakim jest arbitralne wykorzystywanie danych ze spisu powszechnego. Ma to związek z ogólnoeuropejskim (ogólnounijnym) trendem wycofywania z formularzy spisów deklaracji związanych z przynależnością narodową oraz wyznaniem. Tendencja ta polega na traktowaniu powyższych danych jako kwestii prywatnej, kwalifikowanej jako dane wrażliwe, a to powoduje coraz bardziej wyraźna niechęć do deklarowania swojej tożsamości etnicznej lub narodowej, co sprawia, że wyniki spisów powszechnych sq mało przekonujace $e^{55}$. W rezultacie już jest to wykorzystywane w państwach bałkańskich jako pretekst do nieprzeprowadzania takich spisów lub traktowania ich jako niepełne i odwoływania się, w razie potrzeby, do spisów z lat wcześniejszych, które są dowolnie przez państwo uznawane za wiarygodne. W przypadku władz serbskich korzystają one arbitralnie ze spisu powszechnego z 2002 r. jako źródła wiarygodnych statystyk, ponieważ ten z 2011 r. jest niepełny w odniesieniu do pewnych obszarów (chodzi tu o Preszewo i Bujanovac). Tymczasem np. dla ludności boszniackiej spis z roku 2011 jest korzystny,

${ }^{53}$ Kutnić: Србија прогони Буњевце, Grad Subotica.co.rs, 16. 02. 2011, http://www.gradsubotica.co.rs/ kutnic-srbija-progoni-bunjevce/ (dostęp 11. 04. 2016 r.).

${ }^{54}$ Aktualnie Ragmi Mustafa jest jednym z ośmiu członków (jednym z trzech narodowości albańskiej) Ciała Koordynacyjnego Republiki Serbii dla gmin Preszewo, Bujanovac, Medveđa, Koordinaciono telo Vlade Republike Srbije za opštine Preszewo, Bujanovac, Medveđa, Struktura koordinacionog tela, Координационо тело Владе Републике Србије за општине Прешево, Бујановац и Медвеђа, http:/www.kt.gov.rs/sr/articles/o-nama/struktura-koordinacionog-tela/, P. O brad ović, op. cit.

${ }_{55}$ Ze Wstepu, [w:] Polityka etniczna. Teorie, koncepcje, wyzwania, red. H. Chałupczak, R. Zenderowski, E. Pogorzała, T. Browarek, s. 18. 
wskazuje bowiem na wzrost liczby przedstawicieli tej mniejszości na obszarze Sandżaka. Warto też dodać, że formularz spisu w punkcie 21 (przynależność narodowa) zawierał wyjaśnienie, iż zgodnie z art. 47 Konstytucji z 2006 r. ankietowany nie musi podawać przynależności narodowej; analogiczny zapis zawierał punkt 23 (wyznanie), odwołując się do art. 43 tejże Konstytucji ${ }^{56}$. Z punktu widzenia praw człowieka pozwala to wprawdzie na zachowanie większej prywatności, jednak z punktu widzenia choćby praw kolektywnych mniejszości może przynieść - w opinii autorki - bardzo dużą szkodę, zwłaszcza jeśli chodzi o multietniczny region Bałkanów. Polityka anonimowości etnicznej w ramach iluzorycznie chronionych praw człowieka może przynieść fałszywe kreowanie pejzażu etnicznego, wykorzystywane instrumentalnie na linii państwo - mniejszość, gdzie prawdopodobnie wygranym będzie państwo jako podmiot dysponujący faktyczną władzą oraz większą liczbą narzędzi do kreowania obrazu społeczno-politycznego. Aktualnie faktem jest, że na południu Serbii odsetek Albańczyków zatrudnionych w administracji państwowej nie odpowiada odsetkowi tej ludności w regionie, w odniesieniu do spisu z 2002 r. Odnoszenie się do dokumentacji sprzed kilkunastu lat może być o tyle ryzykowne, że mamy do czynienia bardzo często z obszarami biednymi, z których gros osób emigruje, zmieniając pejzaż etniczny, więc uwzględniając demografię danego obszaru, czy nawet gminy, możemy brać pod uwagę duże zmiany w liczbie ludności, które siłą rzeczy dzięki polityce etnicznej państwa nie będą uwzględniane. Na podstawie niepełnego spisu w $2011 \mathrm{r}$. nie tylko nie stwierdzi się, jaki procent przedstawicieli tej ludności powinien być zatrudniony w sektorze publicznym, ale może on dać pretekst władzom serbskim do wykorzystania braku danych, na co nie mają wpływu. Oczywiście, zarówno władze, jak i sama społeczność albańska mogą wskazać arbitralnie inne przyczyny, które są prawdopodobne (z jednej strony brak kwalifikacji ze strony kandydatów, z drugiej zaś polityka dyskryminacyjna lub zwykła niechęć do współpracy międzyetnicznej ${ }^{57}$ ).

\section{Podsumowanie}

W polityce etnicznej Serbii udana koncepcja multietniczności jest realizowana tylko na obszarze wojwodińskiej autonomii, która dotychczas (po 1991 r., czyli od czasu rozpadu Socjalistycznej Federacyjnej Republiki Jugosławii) nie była zagrożona potencjalnym separatyzmem (chociaż od czasu do czasu pojawia się na moment w publicznym dyskursie wątek możliwego odłączenia się od Serbii). Wojwodina posiada tradycyjną autonomię i jest w zasadzie jedynym obszarem, który spełnia standardy multietniczności w europejskim znaczeniu tego słowa. Pozostałe dwa: Sandżak oraz południe Serbii to terytoria, na których zarówno władze serbskie nie chcą przeprowadzać skutecznej integracji i dzielić się władzą z mniejszościami, jak i sama mniejszość, a przynajmniej część jej społeczności, nie chce współpracować z władzami centralnymi w Belgradzie. To osłabia całą grupę mniejszościową i znacznie utrudnia, o ile nie uniemożliwia, jej harmonijną koegzystencję w ramach państwa serbskiego. Przyczyną jest brak identyfikacji z państwem serbskim części mniejszości, zaś ze strony Serbów brak zaufania do mniejszości przedstawicieli

\footnotetext{
56 Zob. Aneks, formularz П-1, strona 2, Попис становништва..., zob. też Устав ...

${ }^{57}$ P. Obradović, op. cit.
} 
niewychodzących poza propozycje tych, którzy współpracują z władzami, a także i obawa, że powierzenie im władzy lokalnej może doprowadzić do separatyzmu terytorialnego, jak to miało miejsce w przypadku Kosowa. Znamienne jest również to, że serbska etnopolityka zaspokajająca prawa mniejszościowe realizowana jest w Wojwodinie, na której obszarze relacje etniczne buduje ponad dwadzieścia zróżnicowanych pod względem etniczności społeczności, zaś w Sandżaku oraz trzech gminach południowych obraz polityki etnicznej kształtują zaledwie po dwie społeczności (Boszniacy i Serbowie oraz Albańczycy i Serbowie), przy czym jedna ze społeczności reprezentuje naród konstytucyjny (tytularny). $Z$ pewnością kardynalne jest tutaj wykazanie się dobrą wolą w podjęciu współpracy ponad podziałami oraz sentymentami nawiązującymi do nie tak dawnych wydarzeń. Trudno jednak wskazać stronę bardziej odpowiedzialną za ów brak dobrej woli ze względu na sprzeczną politykę informacyjną, którą prowadzą obie strony. Przy niepożądanym stanie położenia mniejszości z pewnością łatwiej wskazać jest państwo jako podmiot odpowiedzialny za popełnianie błędów oraz prowadzenie złej polityki narodowościowej, której skutki mogą być aż nadto widoczne (np. brak reprezentacji w administracji, brak skuteczności działania organów, utrzymanie poziomu zacofania regionów). O wiele trudniej jest konsekwentnie wskazać odpowiedzialność mniejszości, zwłaszcza w regionie Bałkanów, gdzie proces przemian systemowych i gospodarczych trwa, zaś mniejszości nie znajdują się w sytuacji w pełni zadowalającej w każdym aspekcie ich życia, ponieważ w takie sytuacji nie znajduje się nawet naród konstytucyjny, czyli Serbowie.

Taka postawa w przypadku analizowanego w tekście obszaru bałkańskiego (serbskiego) potwierdza powyższe stwierdzenia, w jednoznaczny sposób pokazując, dlaczego właśnie wspomniany na początku tekstu paradygmat Hobbesowskiej walki występuje częściej, zaś najwyższym dobrem, o które toczy się walka, jest zakres samorządności nad zamieszkiwanym przez siebie obszarem. Wypływa on mianowicie z polityki realnej i wydarzeń, które nie tylko miały miejsce na obszarze Zachodnich Bałkanów, ale pojawiły się jako poważny problem w Europie ostatnich lat. Doświadczenia te pokazują, że zaledwie część grupy etnicznej dąży do racjonalnej kantowskiej wspótpracy, podczas gdy druga jej część chce przede wszystkim osiągnąć własne cele, którymi są prawa kolektywne w ramach możliwie daleko posuniętej niezależności (aż do ewentualnego pozyskania niepodległości). Należy dodać, że właśnie te grupy mają większy wpływ na obraz relacji etnicznych i w dużej mierze uniemożliwiają współpracę, która mogłaby być kolejnym - kantowskim - etapem. Jednak przejście do tego etapu warunkowałoby uzyskanie pożądanej przez wszystkie podmioty polityki etnicznej sytuacji faktycznej oraz prawnej, która wyczerpywałaby postulaty mniejszościowe, dając im zadowolenie ze swojego położenia. Taki stan jest bardzo trudny do osiągnięcia, jednak nie niemożliwy. Do takiego stanu na obszarze Serbii przybliżyła się właśnie Wojwodina, ale i tak w tym przypadku trudno zaryzykować stwierdzenie o zupełnym zadowoleniu, uwzględniając sytuację na scenie politycznej.

$\mathrm{Z}$ kolei narody konstytucyjne, czyli owe umacniajace uprzywilejowana pozycje i kreujące władzę państwową, mają również trudności z osiągnięciem kantowskiego eta$p u$ z powodu przekonania o konieczności nieustającego postępującego kompromisu z ich strony ze względu na roszczenia mniejszości, które są niemożliwe do zaspokojenia, aż do momentu ich całkowitego uniezależnienia się od organizmu państwowego. Ten brak zaufania związany jest $\mathrm{z}$ historią - również tą najnowszą - uzyskiwania niezależności politycznej przez państwa bałkańskie. Jednostronne ogłoszenie niepodległości, bez po- 
szanowania konstytucji państwowej, wzbudzało, i do dzisiaj wzbudza, obawy, że dana grupa narodowa mogłaby ogłosić niezależność zamieszkiwanego przez siebie terytorium poprzez sukcesywnie uzyskiwanie coraz to większej niezależności. Ten brak zaufania w relacjach etnicznych, głównie w wymiarze wertykalnym, pozostawia sytuację raczej w kategoriach konfliktów zamrożonych lub też nierozwiązywalnych (w rozumieniu Bar-Talowskim ${ }^{58}$ ), zważywszy na bazowanie na tych samych animozjach od dziesiątków lat, które nie ewoluują w kierunku porozumienia lub kompromisowego ujęcia historii najnowszej, mimo zabiegów różnych ośrodków (naukowych czy pozarządowych).

Oceniając politykę etniczną państwa serbskiego wobec omówionych powyżej mniejszości, należy stwierdzić, że w wymiarze formalno-prawnym Serbia realizuje wysokie standardy w stosunku do mniejszości, przy równoczesnym zastrzeżeniu, że nie koresponduje to w każdym przypadku z ich faktycznym położeniem. Na ocenę rzeczywistej etnopolityki składa się bowiem nie tylko zakres wykorzystywania posiadanych w tej polityce narzędzi, zagwarantowanych prawem, ale i czynnik decydujący o przyczynie, charakterze i celu ich wykorzystania, które często pozostają w ukryciu i nie znajdują odnotowania w statystykach lub innych dokumentach.

\section{Bibliografia:}

Dokumenty

1. Najnoviji rezulatati parlamentarnih izbora, Eizbori, http://eizbori.com/rezultati-izbora-2016-srbija/

2. Коначни резултати пописа 2002. Становништво према начионалној или етничкој припадности и према полу и старости у Републици Србији, по општинама, Саопштење број 295 • год. LII, 24.12.2002, Република Србија. Републички завод за статистику, http://www.mtt.org. rs/Srbijapopis2002.pdf

3. O bližem uređivanju pojedinih pitanja službene upotrebe jezika i pisama nacionalnih manjina na teritoriji Autonomne Pokrajine Vojvodine, „Sl. list AP Vojvodine”, br. 8/2003, 9/2003 - ispr. i 18/2009 - promena naziva akta, http://www.hnv.org.rs/docs/POKRAJINSKA\%20Odluka\%20 jezik.pdf

4. Pokrajinska skupštinska odluka o pokrajinskoj upravi, „Službeni list AP Vojvodine”, br. 4/2010, 4/2011, http://www.ljudskiresursi.Wojwodina.gov.rs/downloads/9.\%20Pokrajinska\%20skupstinska\%20 odluka\%20o\%20pokrajinskoj\%20upravi.pdf

5. Попис становништва, домћинства и станова 2011. у Републици Србији. Наионална припадност. Подаци по општинама и градовима, Република Србија, Републички завод за статистику, http://pod2.stat.gov.rs/ObjavljenePublikacije/Popis2011/Nacionalna\%20pripadnost-Ethnicity.pdf

6. Статут Аутономне Покрајине Војводине, 2014, http://www.skupstinavojvodine.gov.rs/fajlovi/file/Statut/Statut\%20AP\%20Vojvodine.pdf

7. Statut Bošnjačkog Nacionalnog Vijeća, „Službeni glasnik RS” br. 72/2009, 20/2014 - odluka US i 55/2014, http://www.bnv.org.rs/wp-content/uploads/2015/06/1.02.-2015-05-Statut-Bo\%C5\%A1nja\%C4\%8Dkog-nacionalnog-vije\%C4\%87a.pdf

8. Устав Републике Србије. 2006, http://www.parlament.gov.rs/upload/documents/Ustav_Srbije_pdf.pdf

${ }^{58}$ D. B a r-Ta1, Podstawy kulturowe i dynamika nierozwiazywalnych konfliktów: podejście socjopsychologiczne, „Psychologia Społeczna” 2013, 1(24) 7-21, http://www.spoleczna.psychologia.pl/pliki/2013_1/ Bar_Tal_PS_1_2013.pdf. 
9. Zakon o lokalnoj samoupravi, „Službeni glasnik RS”, br. 9/2002, 33/2004, file://C:/Users/ Admin/Desktop/Zakon\%20o\%20lokalnoj\%20samoupravi.pdf

10. Zakon o nacionalnim savetima nacionalnih manjina, „Sl. glasnik RS br. 72/09 , 20/14 - US, 55/14", http://www.mduls.gov.rs/doc/dokumenta/nac-manjine/zakon\%20o\%20nacionalnim\%20 savetima\%20nacionalnih\%20manjina.pdf

11. Zakon o službenoj upotrebi jezika i pisama, „Službeni glasnik Republike Srbije”, br. 45/91, 53/93, 67/93, 48/94, 101/2005, 30/2010, http://www.paragraf.rs/propisi/zakon_o_sluzbenoj_ upotrebi_jezika_i_pisama.html

12. Zakon o zaštiti prava i sloboda nacionalnih manjina, (,Sl. List SRJ”, br. 11/2002, „Sl. List SCG”, br. 1/2003 - Ustavna povelja I „Sl. Glasnik RS”, br. 72/2009 - dr. zakon I 97/2013 - odluka US, http://www.paragraf.rs/propisi/zakon_o_zastiti_prava_i_sloboda_nacionalnih_manjina.html

Dokumenty audiowizualne

1. Зоран Станковић о постигнутим резултатима и о ичиљу разговора са албанским лидерима, Координационо тело Владе Републике Србије за општине Прешево, Бујановац и Медвеђа, http://www.kt.gov.rs/cr/video/single/TwECbArGyMU/70/

2. Зоран Станковић о ситуачији у општинама Прешево, Бујановаи и Медвеђа у 2013. Годи$н и$, Координационо тело Владе Републике Србије за општине Прешево, Бујановац и Медвеђa, http://www.kt.gov.rs/cr/video/single/Ot6TKBaaffU/75/, Formirana zajednica albanskih opština, B92, 12. 09. 2015, http://www.b92.net/info/vesti/index.php?yyyy=2015\&mm=09\&d$\mathrm{d}=12$ \&nav_category $=11 \&$ nav_id $=1038405$

\section{Opracowania}

1. Bašić G., Položaj Bošnjaka u Sandżaku, wyd. Centar za antiratnu akciju Mir, Beograd 2002

2. My już jesteśmy zjedzeni...Rola i znaczenie prawosławia w konflikcie etnicznym w Dolinie Preszewa, red. R. Zenderowski, Wydawnictwo Instytutu Politologii Uniwersytetu Kardynała Wyszyńskiego w Warszawie, Warszawa 2012

3. Polityka etniczna. Teorie, koncepcje, wyzwania, red. H. Chałupczak, R. Zenderowski, E. Pogorzała, T. Browarek, Wydawnictwo UMCS, Lublin 2015

4. Polska i Europa wobec wyzwań wspótczesnego świata. Mniejszości narodowe i etniczne w Polsce i Europie. Aspekty polityczne i społeczne, red. A. Sakson, Wyd. Adam Marszałek, Torun 2013

5. Serbia: Maintaining Peace In Preshevo Valley. Europe Report $N^{\circ} 186-16$ October 2007, International Crisis Group, http://www.crisisgroup.org/ /media/Files/europe/186_serbia_maintaining_peace_in_the_presevo_valley.pdf

6. Stawowy-Kawka I., Albańczycy w Macedonii, Wydawnictwo Uniwersytetu Jagiellońskiego, Kraków 2014

Artykuły naukowe

1. Bar-Tal D., Podstawy kulturowe i dynamika nierozwiązywalnych konfliktów: podejście socjopsychologiczne, „Psychologia Społeczna” 2013, 1(24) 7-21, http://www.spoleczna.psychologia. pl/pliki/2013_1/Bar_Tal_PS_1_2013.pdf

2. Chałupczak H., Paradygmat badawczy polityki etnicznej jako polityki publicznej państwa, [w:] Polska i Europa wobec wyzwań wspótczesnego świata. Mniejszości narodowe i etniczne w Polsce i Europie. Aspekty polityczne i społeczne, red. A. Sakson, Wyd. Adam Marszałek, Toruń 2013, s. 11-28

3. Gojković N., Sistem zaštite manjina u Republici Srbiji, http://www.kas.de/upload/auslandshomepages/serbien/Gojkovic_pred.pdf 
4. Korzeniewska-Wiszniewska M., Obraz relacji serbsko-boszniackich na przykladzie Sandżaku w pierwszej dekadzie XXI w., [w:] Bałkany Zachodnie między przeszłościa a przyszłościa, red. P. Chmielewski, S. L. Szczesio, Wyd. UŁ, Łódź 2013

5. Korzeniewska-Wiszniewska M., Położenie mniejszości muzulmańskiej w Republice Serbii po 2008 r. w kontekście serbskich aspiracji wstapienia do Unii Europejskiej, [w:] Problemy aksjologiczne w relacjach Unii Europejskiej z Bałkanami, red. M. Babić, F. Gołembski, Warszawa 2012

6. Korzeniewska-Wiszniewska M., Serbskie aspiracje do struktur europejskich. Sytuacja mniejszości narodowych i etnicznych w Autonomicznej Prowincji Wojwodiny ze szczególnym uwzględnieniem systemu ksztatcenia, [w:] Slavia Meridionalis, t. XII, red. Lilla Moroz-Grzelak, wyd. Slawistyczny Ośrodek Wydawniczy, Warszawa 2012

7. Krzak A., Assymetry of the Albanian-Macedonian Military Conflict in 2001. Military Characteristics of the Fight in the Regions of Tetovo, Kumanovo, Aračinovo and Vaksince, [w:] Macedonia in $20^{\text {th }}$ and $21^{\text {st }}$ century, ,Politeja” $\mathrm{nr} 4(30), 2014$, red. M. Korzeniewska-Wiszniewska

8. Mikucka-Wójtowicz D., Działalność partii mniejszości narodowych w Republice Serbii w latach 1990-2008, [w:] Annales Universitatis Paedagogicae Cracoviensis. Studia Politologica, XI (2013), red. K. Sobolewskiej-Myślik, Wydawnictwo Naukowe UP, Folia 138, Kraków 2013

9. Wierzbicki A., Genetyczno-kulturowe podstawy etnopolityki. Perspektywa etnonacjonalistyczna, [w:] Polityka etniczna. Teorie, koncepcje, wyzwania, red. H. Chałupczak, R. Zenderowski, E. Pogorzała, T. Browarek, Wydawnictwo UMCS, Lublin 2015

10. Zenderowski R., Polityka etniczna - próba (re)konceptualizacji, [w:] Polityka etniczna. Teorie, koncepcje, wyzwania, red. H. Chałupczak, R. Zenderowski, E. Pogorzała, T. Browarek, Wydawnictwo UMCS, Lublin 2015

Artykuły prasowe i internetowe

1. Активности, Координационо тело Владе Републике Србије за општине Прешево, Бујановац и Медвеђа, http://www.kt.gov.rs/cr/articles/aktivnosti/

2. Bojkot nastave zbog nedostatka udžbenika na albanskom jeziku, Južne Vesti, 27. 10. 2015, http:// www.juznevesti.com/Drushtvo/Bojkot-nastave-zbog-nedostatka-udzbenika-na-albanskomjeziku.sr.html Број добијених мандата, Народна Скупштина Републике Србије, http://www. parlament.gov.rs./ народна- скупштина/ народна- скупштина-у- бројкама.1734.html

3. Članovi Pokrajinske Vlade, Republika Srbija. Autonomna Pokrajina Wojwodina, http://www. Wojwodina.gov.rs/sr/\%D1\%87\%D0\%BB\%D0\%B0\%D0\%BD\%D0\%BE\%D0\%B2\%D0\%B8- \% D 0\%BF\%D0\%BE\%D0\%BA\%D $1 \% 80 \%$ D0 \% B 0\%D $1 \% 98 \%$ D0 \% B 8\%D0\%BD\%D1\%81\%D0\%BA\%D0\%B5-\%D0\%B2\%D0\%BB\%D0\%B0\%D0\%B4\%D0\%B5\#

4. Džemail Suljević sanja ,,Sandżak Republiku”, Vesti.rs, 16. 08. 2010, http://www.vesti.rs/Milorad-Dodik/DZEMAIL-SULJEVIC-SANJA-SANDZAK-REPUBLIKU.html

5. Elesković E., Uloga i dostignuća BNV u Sandżaku, „Danas”, 31. 01. 2016, http://www.danas. rs/dodaci/sandzak/uloga_i_dostignuca_bnv_u_sandzaku.42.html?news_id=315192

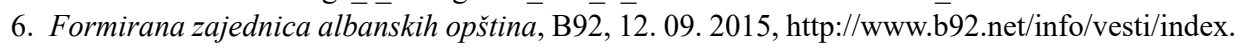
php?yyyy $=2015 \& \mathrm{~mm}=09 \& \mathrm{dd}=12 \&$ nav_category $=11 \&$ nav_id $=1038405$

7. Izbori 2014. za nacjonalne savete nacionalnih manjina, Minority News, http://izbori.minoritynews.rs/nacionalni-savet-albanske-nacionalne-manjine

8. Kutnić: Србија прогони Буњевие, Grad Subotica.co.rs, 16. 02. 2011, http://www.gradsubotica. co.rs/kutnic-srbija-progoni-bunjevce/

9. Miladinović Z., Odobreno 18 projekata za nezaposlene, Vesti.rs. 12. 04. 2011 r., http://www. vesti.rs/Hronika/Odobreno-18-projekata-za-nezaposlene.html

10. Muftija Sandžacki, Islamska Zajednica u Srbiji, http://mesihat.org/muftijstvo-sandzacko/muftija-sandzacki2/ 
11. Musić K., Smanjiti broj naposlenih, ali građani ne trpe, „Danas”, 4. 02. 2016, http://www.danas. rs/dodaci/sandzak/smanjiti_broj_zaposlenih_ali_da_gradjani_ne_trpe_.42.html?news_id=315456

12. Mustafa: tražićemo albansku zastawu milion puta ako treba, N1, 28. 11. 2014, http://rs.n1 info. com/a15591/Vesti/Mustafa-Trazicemo-albansku-zastavu-milion-puta-ako-treba.html

13. Novosel S., Smanjenje broja nezaposlenih, „Danas” 4. 02. 2016, http://www.danas.rs/dodaci/ sandzak/smanjenje_broja_nezaposlenih.42.html?news_id=315462

14. OVijeću, Bošnjačko nacionalno vijeće, http://www.bnv.org.rs/o-nama/

15. Odbori, Bošnjačko nacionalno vijeće, http://www.bnv.org.rs/tijela-bnv/odbori/

16. Obradović P., Između demokratskog i etničkog principa, „Vreme”, nr 1060, 28. 08. 2011, http:// www.vreme.com/cms/view.php?id=988099

17. Посланичке групе, Скупштина Аутономне покрајине Војводине, Република Србија Аутономна покрајина Војводина, http://www.skupstinavojvodine.gov.rs/Strana.aspx?s=poslanicke grupe\#Посланици који нису чланови посланичких група

18. Potpisani ugovori za samozapošljavanje Roma u Vojvodini Vlade Autonomne Pokrajine Vojvodine, 29. 12. 2011, http://www.Wojwodina.gov.rs/index.php?option=com_content\&task=view\&id $=6270 \&$ Itemid $=2$

19. Sandżak, Bošnjačko nacionalno vijeće, http://www.bnv.org.rs/ostalo/sandzak/

20. Sandżak traži „partizansku autonomiju”, Vesti online, 9. 08. 2010, http://www.vesti-online. com/Vesti/Srbija/73585/Sandzak-trazi-partizansku-autonomiju

21. Savet za nacjonalne manjine Zaštitnika građana, Заштитик грађана. Омбудсман. Права мањина, http://www.pravamanjina.rs/index.php/sr_YU/component/content/article/334

22. Struktura koordinacionog tela, Координационо тело Владе Републике Србије за општине Прешево, Бујановац и Медвеђа, http:/www.kt.gov.rs/sr/articles/o-nama/struktura-koordinacionog-tela/

23. Tokom ove godine odobrena 23 projekta, Vesti Istočne Srbije, 17. 04. 2011 r., http://www.istocnasrbija.com/majdanpek/danas-tokom-ove-godine-odobrena-23-projekta

24. Uručeno 260 ugovora za samozapošljavanje, RTV 13. 07. 2011, http://www.rtv. rs/sr_lat/Wojwodina/uruceno-260-ugovora-za-samozaposljavanje_263463.html

25. Заштитик грађана. Омбудсман. Права мањина, http://www.pravamanjina.rs/

Mirella Korzeniewska-Wiszniewska

\section{Ethnic Policy of the Republic of Serbia Towards Selected Minorities after 2009}

\section{Summary}

The concept of ethnic policy has become the subject of studies by political scientists only relatively recently, while the phenomena associated with ethno-politics, according to the definitions given by researchers, have been an area of research within various disciplines since the development of social sciences. The subject of minorities in Serbia (in the area of the Autonomous Province of Vojvodina, Sandžak, the Preševa Valley and the neighbouring communities) is the subject, raised by Polish researchers, and the scope of their research covers the period of the first decade of the $21 \mathrm{st}$ century. The Republic of Serbia is a country, in which relations between minorities evolve not only on the formal and institutional level, but also in real life. The text aims to present the ethnic policy of Serbia in several theoretical aspects, towards selected minority groups, which are representative from the point of view of the presentation of the minority problem in the country.

Key words: ethnic policy of Serbia, minorities in Serbia, Bosniaks in Sandžak, Sandžak, Albanian minority, Presevo, Bujanovac, Medveđa, Vojvodina, minorities in Vojvodina 